Women's nutritional empowerment and their well-being Identifying key drivers in India and Bangladesh

Sudha Narayanan, Udayan Rathore, Mohit Sharma

Indira Gandhi Institute of Development Research, Mumbai February 2019 


\title{
Women's nutritional empowerment and their well-being Identifying key drivers in India and Bangladesh
}

\author{
Sudha Narayanan, Udayan Rathore, Mohit Sharma
}

Email(corresponding author): sudha@igidr.ac.in

\begin{abstract}
This paper uses six nationally representative household surveys from India and Bangladesh to examine the link between women's empowerment and their own nutritional status. Using a recently developed concept of nutritional empowerment, we first assess the degree to which these surveys capture its constituent elements. After identifying the relevant variables in these surveys that best represent the various aspects of nutritional empowerment, we use these surveys to estimate the relative contribution of different factors of nutritional empowerment to women's nutritional outcomes, specifically BMI (in India and Bangladesh) and anemia (in India). While there are a number of approaches to decomposing the contribution of various factors driving nutrition, we present a novel application of the Shapley-Owen decomposition method, hitherto not applied in the context of determinants of nutritional status. This decomposition method reflects not just the independent, standalone contribution of a specific factor, but a factor's contribution including possible interaction with other factors of nutritional empowerment. Consistent across the surveys, we find that resources, particularly those of health and food drive BMI, while resources relating to health and fertility overwhelmingly determine haemoglobin levels (anemia) in India. We also find that the contribution of knowledge and agency correlate positively with resources, suggesting that these dimensions are complementary. Our findings suggest that policies aimed at empowering women must therefore not focus merely on providing knowledge or seek to strengthen women's decision-making roles in the family. Rather, they should prioritize providing health resources to women in constrained settings.
\end{abstract}

Keywords: India, Bangladesh, women, nutritional empowerment, decomposition techniques, Shapley-Owen values

JEL Code: J16, D13, I00, I3 


\title{
Women's nutritional empowerment and their well-being Identifying key drivers in India and Bangladesh ${ }^{1}$
}

\author{
Sudha Narayanan, Udayan Rathore, Mohit Sharma²
}

\begin{abstract}
This paper uses six nationally representative household surveys from India and Bangladesh to examine the link between women's empowerment and their own nutritional status. Using a recently developed concept of nutritional empowerment, we first assess the degree to which these surveys capture its constituent elements. After identifying the relevant variables in these surveys that best represent the various aspects of nutritional empowerment, we use these surveys to estimate the relative contribution of different factors of nutritional empowerment to women's nutritional outcomes, specifically BMI (in India and Bangladesh) and anemia (in India). While there are a number of approaches to decomposing the contribution of various factors driving nutrition, we present a novel application of the Shapley-Owen decomposition method, hitherto not applied in the context of determinants of nutritional status. This decomposition method reflects not just the independent, standalone contribution of a specific factor, but a factor's contribution including possible interaction with other factors of nutritional empowerment. Consistent across the surveys, we find that resources, particularly those of health and food drive BMI, while resources relating to health and fertility overwhelmingly determine haemoglobin levels (anemia) in India. We also find that the contribution of knowledge and agency correlate positively with resources, suggesting that these dimensions are complementary. Our findings suggest that policies aimed at empowering women must therefore not focus merely on providing knowledge or seek to strengthen women's decision-making roles in the family. Rather, they should prioritize providing health resources to women in constrained settings.
\end{abstract}

Keywords India, Bangladesh, women, nutritional empowerment, decomposition techniques, Shapley-Owen values

\footnotetext{
${ }^{1}$ This paper is part of a project titled Women's Empowerment in Nutrition Index (WENI) funded by a grant from Innovative Methods and Metrics for Agriculture and Nutrition (IMMANA) of DFID. Thanks are due to Sweta Bhushan, Monorisha for research assistance and to Anuradha De, Bharati Kulkarni, Chris Barrett, Elizabeth Bageant, Erin Lentz, Joanna Upton and Marzia Fontana for comments and discussions. We alone remain responsible for any errors and omissions that remain.

${ }^{2}$ Sudha Narayanan is Associate Professor, Indira Gandhi Institute of Development Research (IGIDR), Mumbai; Mohit Sharma and Udayan Rathore are Research Associates, Collaborative Research and Dissemination (CORD), Delhi. Detailed results are available with the authors.
} 
The idea that women's status has a significant role to play in the nutritional status of children has long been recognized (Ramalingawami, et al., 1997). Since then, conceptual frameworks for understanding the drivers of nutritional outcomes have provided a more explicit role for the mediating role of women in influencing nutritional outcomes of children. The UNICEF (1990) framework for child undernutrition accommodates immediate causes (diet and disease burdens), underlying causes (access to food and health resources and care for women and children) and basic causes (human, economic and organizational resources). Women's educational levels and work status are typically regarded as part of the basic factors that drive nutritional status. More recently, in the context of linkages between agriculture and nutrition, Kadiyala et al., (2014) identify six pathways from agriculture to nutrition. Three of these six pathways pertain to the nutritional impacts of farm production, farm incomes, and food prices and themselves acknowledge the role of women. The other three explicitly pertain to agriculture-gender linkages, including intra-household distribution of resources, women's role in decision making, their ability to provide care to children while participating in agricultural activities and the implications of work burden and working conditions for maternal nutrition, each hypothesized to affect child nutritional status.

There is now a growing body of evidence that women's status or empowerment is indeed a significant driver of improvements in the nutritional status of children (Cunningham et al., 2015; van Bold et al., 2013 review these). Studies conclude that maternal education (e.g., Behrman \& Wolfe, 1987; Heady 2013; Ruel and Alderman, 2013; Menon et al., 2018), maternal nutrition (Black et al., 2013) and the position of women in the family hierarchy (Coffey et al., 2013; Jayachandran \& Pande, 2013) matter for child nutrition. Studies that construct measures of empowerment also suggest positive associations between women's empowerment (or factors leading to empowerment) and child nutrition (Cunningham et al., 2015; Malapit et al., 2015; Quisumbing \& Maluccio, 2003; Smith et al., 2003). Despite the longstanding recognition that women's status matters for nutritional outcomes of children and recent efforts to empirically validate this relationship, several critical issues remain unresolved (Kadiyala et al., 2014).

First, women's empowerment is a complex, multidimensional phenomenon and it is not consistently clear which aspects of empowerment impact nutritional status of children, or indeed whether a particular aspect of empowerment influences different measures of nutritional status differently (Malapit, et al, 2016). For example, Malapit et al., (2015) suggest that women's empowerment in Nepal is more strongly associated with diet quality than nutrition status and that different aspects of empowerment may have different impacts on nutrition. Cunningham et al., (2015) observe that inconsistencies in findings arise on account of 
differences across studies, in population characteristics, settings, the specific domains studied and the methods/conceptualisations of women's empowerment.

Indeed, a fundamental problem is that there is no consensus on how to measure empowerment (Cunningham et al., 2015; Donald et al., 2017; Pratley, 2016; van Bold et al., 2013). Critics have pointed out that a generalized notion of empowerment does not get us far in trying to explain nutrition and that it is important to measure those aspects of empowerment that are relevant to the outcome of interest (Donald et al., 2017; Pratley, 2016). Yet, more often than not, the empowerment measure used depends largely on what is available in secondary datasets and is typically captured via proxies such as women's education levels, freedom of movement, their role in decision making and so on (Pratley, 2016; van Bold et al., 2013).

Further, most of the work in this area focuses on the nutritional status of children. Whether and how women's empowerment impacts health outcomes or nutritional status of women themselves is not adequately addressed, barring a few studies. ${ }^{3}$ This is a crucial gap in the literature since there is some evidence that within communities, women may fare far worse than either their male counterparts or their children (FAO, et al., 2017; Lentz et al., 2018; Narayanan et al., 2017a). There is also evidence to suggest that women eat last and least and might prioritize the health of other family members ahead of themselves when resources are constrained (Lentz et al., 2018). Given that intergenerational transmission of nutrition is potentially important and there exists a positive relationship between maternal and child nutrition (Black et al., 2013), it is important to understand the drivers of women's own nutritional status.

In this paper, we focus on investigating the relationship between women's empowerment and women's nutritional outcomes using six large surveys from India and Bangladesh. We aim to operationalize a recent conceptualization of nutritional empowerment that has been developed to capture empowerment specific to nutrition (Narayanan et al., 2017a). It encompasses dimensions of empowerment such as knowledge, resources, agency and achievements; these cover the domains of food, health, fertility and institutions, all of which influence nutritional status of women. This conceptualization of empowerment is derived from a normative framework rather than being data-driven; in addition, it focuses on aspects of empowerment that are most related to nutritional outcomes. We ask: which domains and dimensions of nutritional empowerment do these surveys capture, even if they do not explicitly seek to measure nutritional empowerment? We then quantitatively investigate which domains and dimensions of nutritional empowerment contribute most to explaining variations in select

\footnotetext{
${ }^{3}$ Most regressions include women's height attainments or Body Mass Index (BMI) but stop short of examining what drives women's nutritional status to start with.
} 
nutritional outcome indicators for women in the sample, regardless of how comprehensively (or not) these surveys reflect nutritional empowerment.

Our empirical effort runs parallel to the extensive literature on identifying and estimating the contributions of the drivers of nutritional status of children. While researchers in this field have used several decomposition techniques to assess the relative contribution of the determinants of child nutrition (Section 4), we use Shapley-Owen decomposition that has thus far not been used in this context. Whereas existing decomposition techniques capture the marginal contribution of a specific factor, Shapley-Owen decomposition techniques allow us to estimate the contribution of each factor or domain-dimension, allowing for its interaction with all other factors, allowing us to decompose the explained variation in nutritional outcomes between different components of nutritional empowerment.

Our focus is on India and Bangladesh. Together, they account for approximately $80 \%$ of total population in South Asia, which, in turn, accounts for a quarter of the world's population. Both countries fare poorly on health and nutritional indicators, especially of women and children (Black et al., 2008). Though India fared marginally better than Bangladesh in early 1990s, Bangladesh has "leap-frogged" India in the last two decades (CIRCUS, 2006; Heady et al., 2015).4 The key ingredients of Bangladesh's success in improving child nutrition remain relatively unknown (Heady et al., 2015), as indeed are those that drive women's nutritional status. In this context, do Shapley-Owen decomposition techniques offer useful insights into whether and which aspects of women's empowerment matters for women's nutritional status.

Our decompositions using the Shapley-Owen technique indicate that across datasets and for both countries, Health-Resources are a key driver of women's BMI and both Health and Fertility-Resources are overwhelming determinants of haemoglobin levels in India. FoodResources and Food-Agency seem important too for BMI and the latter's contribution is particularly significant in Bangladesh. Further, the relative importance of the contribution of different domain-dimensions is largely unrelated to the relative coverage in the surveys. Our results resonate with earlier findings that access to health care (including water and sanitation) matters; we additionally find that contribution of Knowledge, Agency and Resources are positively correlated, suggesting that they complement one another. We find that where Resources matter, Knowledge and Agency also contribute significantly to the nutritional status of women and vice versa.

The paper is structured as follows. We first discuss the concept of nutritional empowerment (Section 2). In Section 3, we describe the six datasets used in this study and

\footnotetext{
${ }^{4}$ For example, while Bangladesh had a much higher infant mortality rate than India in 1990 (91 and 80 per 1,000 live births, respectively), today the positions are reversed: 56 per 1,000 in Bangladesh compared with 62 per 1,000 in India (CIRCUS, 2016)
} 
assess their ability to adequately capture the idea of nutritional empowerment. In Section 4, we discuss the empirical model used to assess the contribution of different components of nutritional empowerment. This includes a review of existing decomposition methods used in the literature, a discussion of the Shapley-Owen decomposition approach and the regression model we estimate. We present our findings in Section 5, where we examine the sensitivity of our estimates. Section 6 concludes the paper with directions for future work and policy implications.

\section{Conceptualizing nutritional empowerment and the WEN Grid}

Recent critiques of constructs of empowerment suggest a large variation in conceptualizations and measurements. While some focus on ownership and control over assets, others focus on agency, represented mainly by the ability of women to participate in decisionmaking. Still others rely on general indicators such as literacy and education levels, social norms (especially of freedom of movement) or of labour market status, political representation, household structure, etc. In a recent systematic review of quantitative evidence exploring the link between women's empowerment and health outcomes, Pratley (2016) identified as many as 121 unique indicators of empowerment. Most of these were typically in the form of an index, each drawing on available survey data, often only notionally linked to existing definitions of empowerment. Even for a specific aspect of empowerment, such as agency, for example, existing attempts at measurement have been partial, offering, at best, a fragmented view (Donald et al., 2018; Doss et al., 2018; van Bold et al, 2013). There is a recognized need to anchor measures of empowerment in normative terms rather than relying on existing data to derive proxy measures for empowerment (Kabeer, 1999b).

Another potential problem with deriving these measures from existing surveys is that they might not capture those elements of empowerment that matter for women's nutrition. Empowerment in one domain, for example, in agriculture might not necessarily translate into empowerment in the domain of nutrition (Narayanan, et al., 2017a). There is increasing realization that generic measures of empowerment might not work for specific outcomes of interest and constructs need to be attuned specifically for the question at hand (Doss et al., 2018; Donald et al., 2018; van Bold, et al., 2013). Pratley (2016) notes, for example, "a health specific dimension of empowerment is virtually absent in the current literature" (Pratley, 2016: 120)..$^{5}$

\footnotetext{
${ }^{5}$ Among recent attempts, the Women's Empowerment in Agriculture Index (WEAI) offers an example of a normative basis for measuring empowerment and attempts to incorporate nutrition explicitly as part of the index (Alkire et al., 2013).
} 
Conceptualizing and measuring empowerment is, however challenging because it is complex, multidimensional and comprises interdependent aspects (Donald et al., 2018; Kabeer, 1999a; van Bold et al., 2013). Kabeer views empowerment as the "expansion in people's ability to make strategic life choices in a context where this ability was previously denied to them" (p.19). Changes in the ability to exercise choice involve three inter-related dimensions that make up choice: resources (the conditions under which the choices are made), agency (the ability to define one's goals and act upon them; both of which are central to the process by which choices are made), and achievements (the outcomes of choices). Kabeer (1999a) argues that these dimensions are interdependent.

In this study, we use the recently developed concept of nutritional empowerment (Narayanan et al., 2017a; Table 1) that aims to capture empowerment, specific and salient to the nutritional outcomes. It draws on Kabeer's (1999a) conceptualization of empowerment and combines it with the UNICEF (1990) framework describing the drivers of nutrition.

Nutritional empowerment is then conceptualized as the process by which individuals acquire the capacity to be well fed and healthy, in a context where this capacity was previously denied to them. This process entails acquiring knowledge about, and a say over, nutritional and health practices; gaining access to and control over intake of adequate and nutritious food; and being able to draw support from both family and other institutions to secure and maintain an adequate diet and health. This process thus implies changes at the level of both individuals' ability to act and at the level of broad structures constraining a fairer distribution of resources and power (Narayanan et al., 2017a).

Narayanan et al., (2017a) identify the domains of Food, Health and Fertility, with Work working through both the domains of Food and Health. Institutions, a domain in itself, is conceptualized as an overarching set of factors supporting each of the other domains. These domains are consistent with the UNICEF framework (1990) on the drivers of child malnutrition and also incorporate more recent conceptualizations of women's role in mediating agriculturelinkages with nutrition proposed by Gillespie \& Kadiyala (2012).

Each of these domains comprises different dimensions of empowerment - namely, Knowledge, Resources and Agency, following Kabeer (1999b). The combination of domains and dimensions, along with Institutions then constitute a matrix that is referred to as the Women's Empowerment and Nutrition Grid (WEN Grid), whose elements explain nutritional outcomes of women.

The Food domain captures women's knowledge of nutrient content of food, nutritional requirements at different stages of the life cycle (e.g. during pregnancy) and cooking practices; in addition it includes knowledge of food assistance and credit programmes; terms of access to land and common property resources (as sources of food) and paid work (as potential source of 
both income and agency); availability of both markets for food and public provision of food; family norms around eating.

The Health domain includes knowledge of WASH practices as well as awareness of disease transmission and treatment, awareness of public health services, total workload as well as paid/unpaid work ratios, work status and use of labour saving technologies, availability of WASH infrastructure, quality and accessibility of health facilities, health-seeking and time-use.

The Fertility domain encompasses knowledge of contraception, immunization, and dietary and feeding practices, both during pregnancy and after delivery. It also includes access to relevant schemes, facilities, and decision-making around marriage, contraception and number of children.

Institutions comprise media access, acceptance of women's participation in public life as well as safety of public spaces, extent of hierarchy in household structures, opportunities for collective action, availability and effectiveness of legal support specifically for women.

While in Kabeer's (1999b) characterisation of empowerment, achievements too represent one dimension, our goal is to seek to explain achievements in nutrition and the extent to which empowerment drives these achievements. In this paper, we use BMI and haemoglobin levels (representing anemia), two widely accepted measures of nutritional status, as outcome variables.

\section{The WEN Grid and existing survey data: A Mapping Exercise}

We identify six datasets from India and Bangladesh that have information on health and nutritional outcomes of women that are also nationally representative or represent a majority of the country.

We consider four datasets from India and two from Bangladesh (Table 2). The Indian datasets include (i) National Family and Health Survey-3 (henceforth India-NFHS-3), 2005-2006 (ii) National Family Health Survey-4 (India-NFHS-4), 2014-2015 (iii) District Level Household and Facility Survey (India-DLHS-4), 2012-2013, and (iv) Indian Human Development Survey (IHDS-2), 2011-2012. The Bangladesh datasets include (v) Bangladesh Integrated Household Survey (BIHS), 2015, and (vi) Bangladesh Demographic and Health Survey (Bangladesh-DHS), 2014. 
Table 1: The WEN Grid

\begin{tabular}{|c|c|c|c|c|c|c|}
\hline \multicolumn{2}{|c|}{$\begin{array}{l}\text { DIMENSIONS } \\
(\Leftrightarrow) \\
\text { DOMAINS }(\Downarrow)\end{array}$} & \multirow{2}{*}{$\begin{array}{ll}\begin{array}{l}\text { Knowledge } \\
\text { (Knowledge of) }\end{array} \\
1 . & \text { Nutrition } \\
2 . & \text { Special diets } \\
3 . & \text { Government schemes (self- } \\
& \text { employed, trainings, farming) }\end{array}$} & \multirow{2}{*}{$\begin{array}{l}\text { Resources } \\
\text { (material and social resources, structural conditions/norms) } \\
\text { 1. Access to remunerative paid work } \\
\text { 2. Opportunities for year-long employment (Private/government/ NGOs) } \\
\text { 3. Opportunities of self-employment (capital/credit, market, } \\
\text { livestock, land, forest access, training) } \\
\text { 4. Access to food (Market purchases Production, State schemes, CPR, NGOs/Civil society } \\
\quad \text { Organizations/SHGs) } \\
\text { 5. Consumption norms } \\
\text { (a) Eating order } \\
\text { (b) Fasting } \\
\text { (c) Taboos (vegetarianism, milk avoidance) } \\
\text { 6. Time available (for paid work, or collect and prepare food) }\end{array}$} & \multirow{2}{*}{$\begin{array}{l}\text { Agency } \\
\text { (Executive \& Implementation) } \\
\text { 1. Decisions around } \\
\text { (a) Food production } \\
\text { (b) Procurement, } \\
\text { (c) Preparation } \\
\text { (d) Distribution } \\
\text { 2. Control over income and expenditure } \\
\quad \text { on food types and budgets }\end{array}$} & \multirow{2}{*}{$\begin{array}{l}\text { Intermediate } \\
\text { Achievements } \\
\text { 1. Food Adequacy } \\
\text { 2. Coping strategies } \\
\text { Index } \\
\text { 3. Dietary Diversity }\end{array}$} & $\begin{array}{l}\text { Final } \\
\text { Achievem- } \\
\text { ents }\end{array}$ \\
\hline 1 & : & & & & & $\begin{array}{c}\text { BMI } \\
\text { Anemia }\end{array}$ \\
\hline 2 & 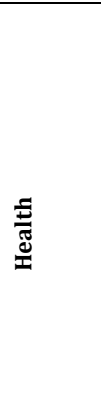 & $\begin{array}{ll}\text { 1. } & \text { WASH } \\
2 . & \text { Immunization } \\
\text { 3. } & \text { Any specific endemic disease }\end{array}$ & $\begin{array}{l}\text { 1. Working conditions } \\
\text { (a) Effort and intensity (paid and unpaid work) } \\
\text { (b) Exposure to hazardous conditions } \\
\text { (c) Fair distribution between paid \& unpaid work } \\
\text { 2. Technologies and infrastructure (type, time, effort) } \\
\text { (a) Fuel } \\
\text { (b) Water } \\
\text { (c) At work: on and off-farm } \\
\text { 3. Facilities (Govt. and private, traditional, temple, etc.) and assistance in tasks from } \\
\text { others (household, paid, community, etc.)) } \\
\text { 4. Financing (subsidies) } \\
\text { 5. Initiatives for specific diseases (polio, malaria) }\end{array}$ & $\begin{array}{l}\text { 1. Decisions around } \\
\text { (a) Health seeking } \\
\text { (b) Toilet construction } \\
\text { (c) WASH } \\
\text { 2. Control over time } \\
\text { (a) Leisure } \\
\text { (b) Type of work } \\
\text { (c) Tasks, sleep/rest } \\
\text { 3. Control over use of money for } \\
\text { health relative investments }\end{array}$ & $\begin{array}{l}\text { 1.1.1 Morbidity } \\
\text { 1. Chronic, } \\
\text { 2. Long-term, } \\
\text { 3. Temporary } \\
\text { 4. Specific diseases: } \\
\text { mental, menopausal }\end{array}$ & \\
\hline 3 & 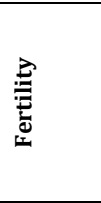 & $\begin{array}{l}\text { 1. Contraception, } \\
\text { 2. Immunization } \\
\text { 3. Colostral feeding } \\
\text { 4. Pregnancy/feeding practices }\end{array}$ & $\begin{array}{l}\text { 1. Facilities } \\
\text { 2. Financing } \\
\text { 3. Schemes } \\
\text { 4. Contraception }\end{array}$ & $\begin{array}{l}\text { Decisions around } \\
\text { (a) Marriage } \\
\text { (b) Children } \\
\text { (c) Contraception } \\
\text { (d) Food during pregnancy and } \\
\text { lactation }\end{array}$ & $\begin{array}{l}\text { 1. Birth spacing } \\
\text { 2. Parity } \\
\text { 3. Child mortality } \\
\text { 4. Age at marriage and } \\
\text { first pregnancy }\end{array}$ & \\
\hline 4 & $\begin{array}{l}\text { Institu- } \\
\text { tions }\end{array}$ & $\begin{array}{l}\text { 1. Decisions around movement, } F \\
\text { 2. Access to media (newspaper, } \mathrm{r} \text {, } \\
\text { 3. Expression of dissatisfaction or } \\
\text { 4. Sources of conflict } \\
\text { 5. Government programs }\end{array}$ & $\begin{array}{l}\text { dom to visit family, Membership in groups, veil, support at the time of crisis } \\
\text { TV), Bank account and its operation, mobile phone access and use, as information source } \\
\text { agreement }\end{array}$ & & & \\
\hline
\end{tabular}


Table 2: Datasets used in this study

\begin{tabular}{|c|c|c|c|}
\hline Dataset & About the dataset & Coverage and period & Sample description \\
\hline $\begin{array}{l}\text { India-NFHS-3 } \\
(2005-06) \\
\quad \text { and } \\
\text { India-NFHS-4 } \\
(2015-16)\end{array}$ & $\begin{array}{l}\text { Survey themes: Socio-demographic } \\
\text { characteristics, household amenities, } \\
\text { morbidity, risk factors, healthcare use and } \\
\text { mortality. } \\
\text { Key Respondents: Eligible women [15-49] } \\
\text { years and men [15-54] years. }\end{array}$ & $\begin{array}{l}\text { India-NFHS-3 (2005-06): } \\
\text { Nationally representative data, } \\
\text { collected across } 29 \text { states } \\
\text { between November } 2005 \text { and } \\
\text { August } 2006 . \\
\text { India-NFHS-4 (2015-16): } \\
\text { Nationally representative at the } \\
\text { district level across } 640 \\
\text { districts in } 29 \text { states, January } \\
2015 \text { to December } 2016 \text {. }\end{array}$ & $\begin{array}{l}\text { India-NFHS-3 (2005-06): } \\
\text { 109,041 households with } \\
\text { 124,385 eligible women. } \\
\text { Analysis based on } 67,424 \text { rural } \\
\text { women. } \\
\text { India-NFHS-4 (2015-16): } \\
601,509 \text { households with } \\
699,686 \text { eligible women. } \\
\text { Analysis based on } 24,662 \text { rural } \\
\text { sample of eligible women who } \\
\text { were administered all modules } \\
\text { of the questionnaire. }\end{array}$ \\
\hline $\begin{array}{l}\text { India-DLHS- } \\
4(2012-14)\end{array}$ & $\begin{array}{l}\text { Survey themes: Socio-demographic } \\
\text { characteristics, household amenities, } \\
\text { morbidity, risk factors, healthcare use, } \\
\text { mortality. } \\
\text { Key Respondents: Eligible women [15-49] } \\
\text { years and men [15-54] years. }\end{array}$ & $\begin{array}{l}\text { Representative at the district } \\
\text { level, it covers only } 18 \text { states } \\
\text { and } 5 \text { union territories of India } \\
\text { for } 336 \text { districts, and was } \\
\text { collected between December } \\
2012 \text { to } 2014 \text {. }\end{array}$ & $\begin{array}{l}947,784 \text { individuals across } \\
220,014 \text { households in rural } \\
\text { and } 648,711 \text { individuals across } \\
156,488 \text { households in urban } \\
\text { areas respectively. Analysis } \\
\text { based on 161,485 rural women } \\
\text { for whom anthropometric } \\
\text { measures were recorded. }\end{array}$ \\
\hline $\begin{array}{l}\text { IHDS-2 } \\
\text { (India) } \\
2011-12\end{array}$ & $\begin{array}{l}\text { Survey themes: Health, education, } \\
\text { employment, economic status, marriage, } \\
\text { fertility, gender relations, social capital, } \\
\text { village infrastructure. } \\
\text { Key Respondents: Eligible women [15-49] } \\
\text { years and men [15-54] years, village } \\
\text { respondents. }\end{array}$ & $\begin{array}{l}\text { Nationally representative panel } \\
\text { data with } 85 \% \text { households re- } \\
\text { interviewed from } 2004-2005 \\
\text { (IHDS-1), covering } 384 \text { districts } \\
\text { in } 28 \text { states and conducted } \\
\text { between } 2011 \text { and } 2012 .\end{array}$ & $\begin{array}{l}\text { I } 42,152 \text { households and } \\
\text { included } 39,253 \text { eligible } \\
\text { women [15-49] years. Analysis } \\
\text { based on 25,418 rural, eligible } \\
\text { 'women for whom } \\
\text { anthropometric and other } \\
\text { details were available. }\end{array}$ \\
\hline $\begin{array}{l}\text { Bangladesh- } \\
\text { DHS (2014) }\end{array}$ & $\begin{array}{l}\text { Survey themes: Anthropometry, } \\
\text { micronutrients, women's status, service } \\
\text { availability, child labour, abortion. } \\
\text { Key Respondents: Ever married women } \\
\text { [15-49]. }\end{array}$ & $\begin{array}{l}\text { Nationally representative data } \\
\text { covering all seven } \\
\text { administrative regions, June - } \\
\text { November } 2014 \text {. } \\
\text {. }\end{array}$ & $\begin{array}{l}\text { 17,300 households and } 17,863 \\
\text { ever married women [15-49] } \\
\text { years. Analysis based on } \\
11,696 \text { rural women }\end{array}$ \\
\hline $\begin{array}{l}\text { BIHS } \\
\text { (Bangladesh) } \\
2015\end{array}$ & $\begin{array}{l}\text { Survey themes: plot level agricultural } \\
\text { production, dietary intake and } \\
\text { anthropometric measures of individual } \\
\text { members, community survey. } \\
\text { Key Respondents: All male and female } \\
\text { members in the household. }\end{array}$ & $\begin{array}{l}\text { Nationally representative for } \\
\text { rural Bangladesh and for rural } \\
\text { areas in its seven } \\
\text { administrative regions } \\
\text { January- June } 2015 \text {. }\end{array}$ & $\begin{array}{l}\text { 6,500 households. Analysis } \\
\text { based on 5,072 women who } \\
\text { were administered Women } \\
\text { Empowerment In Agriculture } \\
\text { Index (WEAI) questionnaire. }\end{array}$ \\
\hline
\end{tabular}


We selected these datasets because each of these surveys has been used extensively in the literature on health and nutrition. The India-NFHS surveys and the Bangladesh-DHS surveys are similar in scope and content as both are part of the DHS survey, administered in multiple countries across the world. The IHDS was collected as part of a panel designed to be representative at the national level, covers a broad range of themes and was not intended as a health survey. The BIHS, also part of a panel, representative of rural Bangladesh across all seven of the country's administrative divisions. In both these panel datasets, we focus only on the most recent round. Table 2 describes these datasets in detail. We focus on rural women aged 15-49, for whom we have data on health and nutritional status. This is because the concept of nutritional empowerment has been developed for the rural context, although extending it to urban contexts is eminently feasible. We use data on individuals, as well as household characteristics and community or village characteristics, where available.

We then assess the extent to which these surveys capture all the relevant domains and dimensions of women's nutritional empowerment. We make these assessments on the basis of whether or not there are any questions that pertain to each of the cells in the WEN Grid and the number of such questions in each cell. We have less to say about whether or not these are the right questions to ask from the perspective of measuring empowerment, although this would matter significantly in the context of identifying the extent to which these variables can predict nutritional outcomes.

A detailed mapping of the questions to the WEN Grid for each survey is available from the authors (an abridged representation is available in Table 3). Here, we restrict ourselves to making some key observations. In mapping the surveys to the WEN Grid, we classify income sources as part of Food-Resources since in the rural South Asian context a large share of the household budget is routinely spent on food. Access to land is similarly classified under Food-Resources. We interpret knowledge to be both nutritional and health knowledge as well as awareness of food aid/health programmes and of income generation and credit programmes. We treat work as a food resource due to its potential to generate income, but as a 'negative' health resource because it entails the expenditure of energy. We also classify norms as part of resources, because they are structural conditions that influence /impede access to resources (Narayanan, et al., 2017). Based on this, we map survey questions to each domain-dimension of nutritional empowerment in the WEN Grid.

In the six surveys considered, not all domain-dimensions of nutritional empowerment are represented to the same degree. In some cases, they are not 
represented at all. This is inevitable since these surveys were not fielded specifically to measure nutritional empowerment. Overall, among the different dimensions of the WEN grid, Resources appears to have the predominant focus, relative to Knowledge and Agency. The overarching domain of Institutions appears to be well covered in all the surveys. Among other domains, Food is covered the least, Health the most. In particular, there is negligible coverage of Food-Knowledge across these surveys. The BIHS (Bangladesh) and IHDS-2 (India) cover Food-Agency better than other surveys. Overall, there seems to be a strong emphasis on Health-Resource in the India-NFHS, India-DLHS and Bangladesh-DHS, unsurprising because these are primarily intended as health surveys.

There are also significant differences in the strength of coverage, as measured by the number of questions per domain-dimension in the WEN Grid (Figure 1). There appears to be a comparable number of questions across surveys for a specific domaindimension rather than across domain-dimensions within a specific survey. Variation in coverage of a specific domain-dimension is because some surveys capture community or village level factors better. For example, both the India-DLHS-4 and IHDS-2 (India) focus on health facilities at the village level and hence capture Health-Resources more comprehensively than the other surveys.

The number of questions is admittedly a poor indicator of whether or not the relevant domain-dimension is well represented. It may be the case that to capture a domain-dimension appropriately, one needs to ask more questions. For example, to obtain a variable for access to healthcare, one might require several questions to gauge affordability, quality and ease of access, in terms of both physical access and staff attitudes. For some other factors, the precise nature of the question may be more crucial than the number of questions, i.e., one question might successfully capture a latent factor. In this sense, even a small set of relevant questions can lead to a 'good' representation of the elements in the WEN grid. We assess this briefly in the last section of this paper. 
Table 3: A simplified list of variables from the DHS/NFHS surveys used for Shapley-Owen analysis

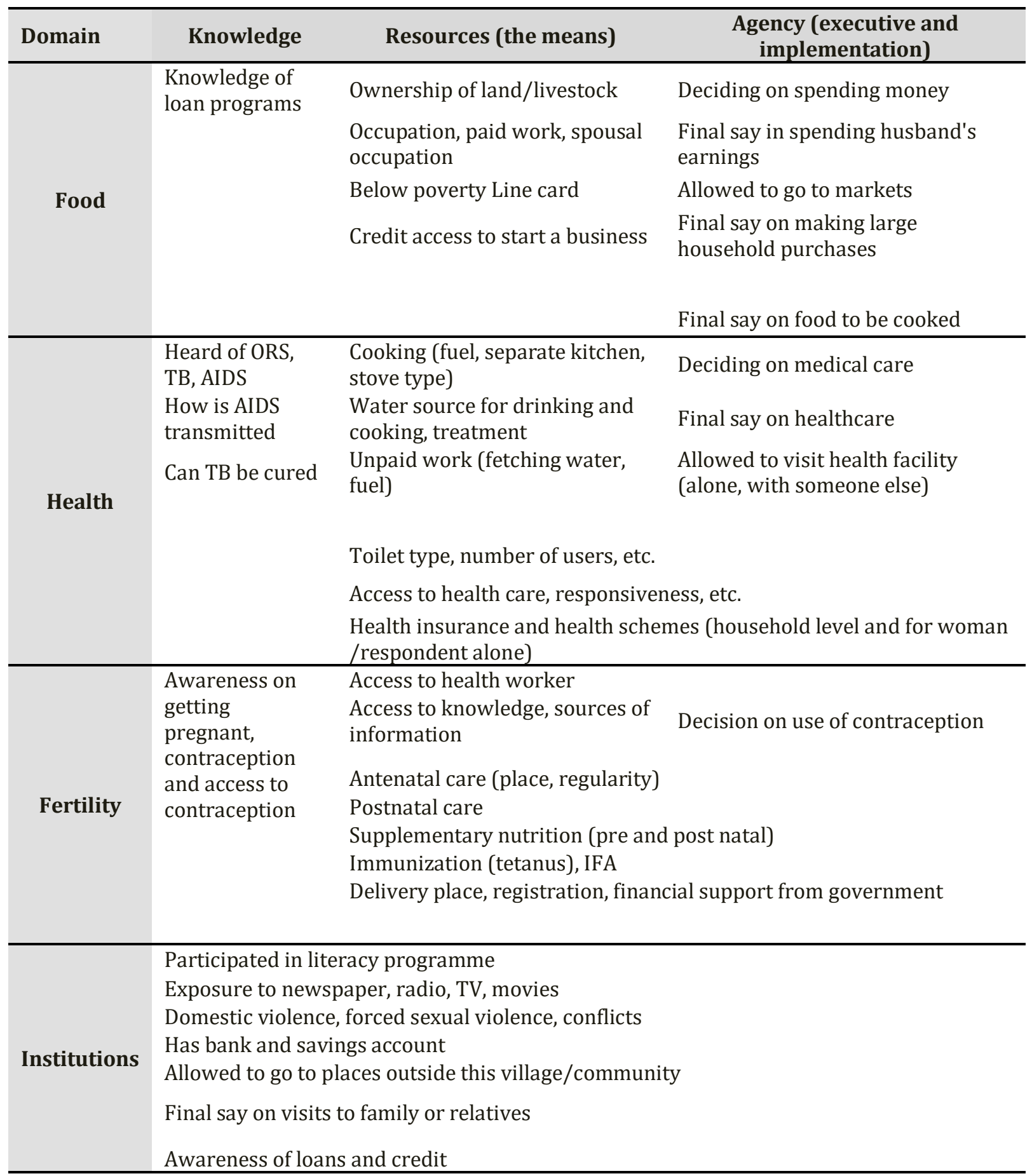

Other controls include: Other household member's characteristics (spousal education, household owns house), Physiological status (pregnancy status, duration, age), marital status, religion and social group. 
Figure 1: Coverage of the WEN Grid by different surveys

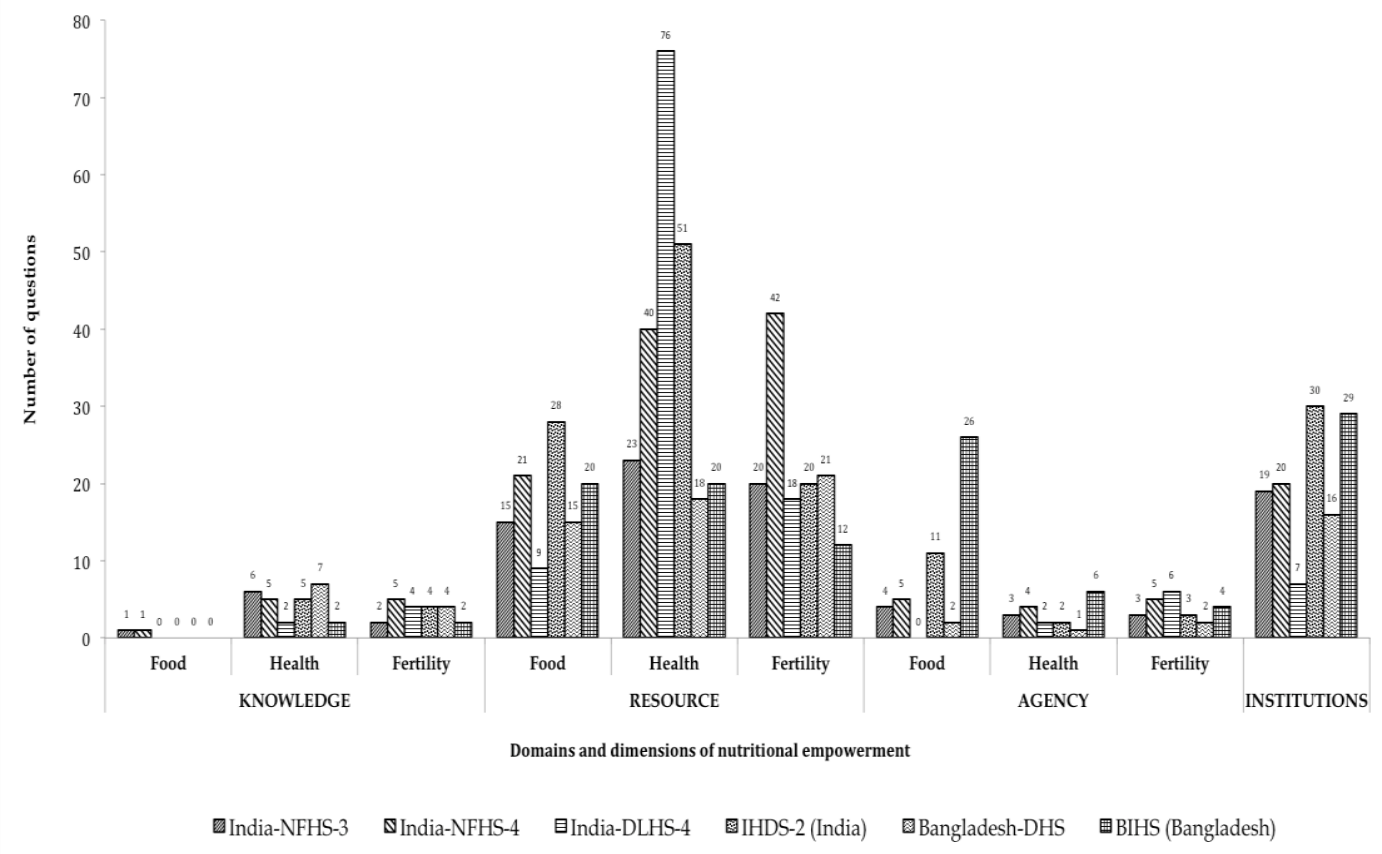

Source: Authors' calculations

\section{Methods}

\subsection{Decomposition methods in the literature}

Many studies aim to identify the drivers of nutrition and a number of quantitative methods have been used to do this (summarized in Appendix Table 1). The simplest of these methods involves using a linear regression model that estimates the association between nutritional status (of women or children) and the various potential drivers of nutrition. The sign, significance and magnitude of regression coefficients are then interpreted as representing the direction and strength of this association. Most such studies use cross-sectional regressions, using data at a specific point of time. The choice of variables to include in these regressions is usually based on the UNICEF Framework (1990) for nutrition, whereby an attempt is made to incorporate proxy variables, representing immediate, underlying and basic causes. Many studies also attempt to include covariates representing women's empowerment via proxies (Kim et al., 2017, Bhagowalia et al., 2012 are examples). Others construct indices of empowerment that aggregate different dimensions/domains into a single variable and use the index as a covariate. The components of these indices typically vary widely (Pratley, 2016). Studies that assess the relationship between Women's Empowerment in Agriculture Index (WEAI) and nutritional status of women and children, for example, fall in this category 
(Malapit et al., 2015a; Sraboni et al., 2013). There are however limitations of interpreting coefficients using regression. Not only are they sensitive to specification and model selection, regression coefficients measure the marginal impact of a particular variable, conditioned on other covariates and as such, this poses problems when variables are highly correlated with one another. Further, for policymakers choosing among multiple interventions, significance tests do not offer guidance for actionable policies, as they do not always allow the ranking of the explanatory variables in order of importance. Another approach uses data reduction techniques, such as factor analysis, to identify latent variables that represent or proxy empowerment (Miedema et al., 2018). The coefficient of factors identified through these data reduction techniques in a regression framework is then interpreted as strength of the association (Sinharoy, et al., 2018, for example, use structural equation modelling or SEM).

More recently, regression decomposition techniques have been used to identify drivers of nutrition that also address some of the limitations associated with the simple interpretation of regression coefficients. Most of these are modifications of the Kitagawa-Blinder-Oaxaca decomposition. The original formulation identifies that part of the difference in mean outcomes $(\bar{Y})$ between two surveys (say, $a$ and $b$ ) that comes from differences in mean endowments $\left(\bar{X}_{a}\right.$ and $\left.\bar{X}_{b}\right)$ and that part that comes from differences in coefficients $\left(\beta_{a}\right.$ and $\left.\beta_{b}\right)$ and this decomposition can be written into ways, depending on whether the reference survey is $a$ or $b$.

$$
\begin{aligned}
& \bar{Y}_{a}-\bar{Y}_{b}=\left(\bar{X}_{a}-\bar{X}_{b}\right) \cdot \beta_{a}+\bar{X}_{a}\left(\beta_{a}-\beta_{b}\right) \\
& \bar{Y}_{a}-\bar{Y}_{b}=\left(\bar{X}_{a}-\bar{X}_{b}\right) \cdot \beta_{b}+\bar{X}_{b}\left(\beta_{a}-\beta_{b}\right)
\end{aligned}
$$

The coefficients in the decomposition above come from the following sample specific regressions:

$$
\begin{aligned}
& Y_{a i}=X_{a i}{ }^{\prime} \beta_{a}+\varepsilon_{a i} \\
& Y_{b i}=X_{b i}{ }^{\prime} \beta_{b}+\varepsilon_{b i}
\end{aligned}
$$

Here, $a$ and $b$ could represent sub-groups of a population or two different communities, two regions/states, two locations - rural and urban areas, or two points of time. $Y_{i}$ is the nutritional outcome of a woman in $a$ or $b, X$ is a vector of factors identified as potential drivers of nutrition, $\beta$ is the least squares estimate measuring the strength of linear association between the respective covariate and the outcome variable and $\varepsilon_{\mathrm{i}}$ is the random error term. The two ways of decomposing the difference in mean outcomes, i.e., (1) and (2) could however lead to different results. One solution is therefore to estimate 
a pooled regression (5) and instead estimate (6) as in Nguyen et al. (2017), Sharaf et al. (2016) and Cavatorta et al. (2012).

$$
\begin{aligned}
& Y_{i}=X_{i}{ }^{\prime} \beta+\varepsilon_{i} \\
& \bar{Y}_{a}-\bar{Y}_{b}=\left(\bar{X}_{a}-\bar{X}_{b}\right) \beta+\bar{X}\left(\beta_{a}-\beta_{b}\right)
\end{aligned}
$$

These coefficients and covariates might vary across the distribution of the nutritional status. As a result, some researchers use Quantile Regression based Counterfactual Decomposition (QR-CD), which allows for variation in coefficients by quantile (Cavatorta et al., 2012;Srinivasan et al., 2013, for example)

Critics point out that, on the one hand, the difference, i.e., $\beta_{a}$ and $\beta_{b}$ could be because the strength of the relationship between $X$ and $Y$ is indeed different across samples $a$ and $b$. However, this difference could also be driven by the absence of variation in measured $X$ in one of the samples (Headey et al., 2015). To illustrate, it could well be that in $a$, a few have access to piped water and others do not, and $\left(\beta_{a}\right)$ could therefore be very high because piped water access matters for women's nutritional status. If, in sample $b$, there is near universal piped water supply, then there would be very little variation in sample $b$ with respect to the $X$ variable for piped water and the coefficient $\left(\beta_{b}\right)$ could be low. This lack of variation in the current period/specific location may erroneously suggest that the variable is unimportant in determining nutritional outcomes. Thus, some prefer to estimate the following Equation (8) instead. The decomposition of the change in average outcomes is then given as:

$$
\bar{Y}_{a}-\bar{Y}_{b}=\left(\bar{X}_{a}-\bar{X}_{b}\right) \beta
$$

The implicit assumption that $\left(\beta_{a}=\beta_{b}\right)$ or that a factor driving nutrition has the same strength of relationship across $a$ and $b$, is a strong one; those who use this approach opt to verify parameter stability via methods like the Chow test (Headey et al., 2015). This technique has been used in the context of both cross-sectional and repeated cross-sectional and panel data (Menon et al., 2018; Headey et al., 2015)

This last technique apportions the difference in average nutritional status across two samples to the differences in the average covariates between the two samples multiplied by their respective coefficients estimated in the pooled regression. An individual covariate's contribution to explaining the difference in $Y$ is thus high if that variable either has a large regression coefficient or has an endowment of $X$ that is very 
different across the two samples, or both. This value is often represented as a proportion of explained variation (R-squared) of the pooled regression model to determine the relative importance of a specific $X$. Often, only a subset of covariates or factors (or $X \mathrm{~s}$ ) are considered, and are limited to those with a statistically significant relationship with the outcome variable.

Despite its evident ease of execution, there are important limitations of this technique. The restrictive assumption that coefficients of $X$ is the same in both samples $a$ and $b$ may not hold in many contexts. Second, by exclusively considering the set of significant variables for decomposition, the method does not take into account that the absence of a statistically significant coefficient might be because relevant drivers are correlated. Headey et al. (2016) address this by selecting variables that exhibit a low correlation (Headey et al., 2017; Headey et al., 2015; Cavatorta et al., 2015).

Another technique that offers insights for policy without necessarily identifying what policy levers to target is variance decomposition. It is used to assess whether, in multilevel data, nutritional status is driven by individual factors, household level factors or community or regional characteristics (Desai \& Thorat, 2013. Desai \& Thorat (2013) find, for example, village characteristics contribute far more than across state variation in stunting outcomes in the India-NFHS (2004-05) sample suggesting that region-level interventions could be more influential than those targeting at household or individuals.

Most of these decomposition techniques assess the independent or marginal contribution of a specific factor, conditioned on other factors. Yet, there is widespread recognition that these factors do not work independently of one another but work synergistically instead, often multiplicatively rather than additively (Desai \& Thorat, 2013; Heady et al., 2017; Menon et al., 2018, World Bank, 2018). Ideally, therefore, we would want to capture the contribution of each explanatory variable allowing for its contribution when it interacts with other factors (World Bank, 2018 takes this approach). Such interactions however need to be explicitly specified and is therefore somewhat subjective. These limitations are well recognized but remain largely unaddressed.

\subsection{Shapley- Owen decomposition}


In response to the limitations of the Kitagawa-Blinder-Oaxaca approach, we propose a novel application of the Shapley-Owen decomposition technique to identify the key empowerment-related drivers of nutritional status of women. This technique offers a unique way to obtain the contribution of each variable in a manner that accounts for its interactions with other covariates in the regression equation (Huettner \& Sunder, 2012; Israeli, 2007). Importantly, the contribution of a variable may be large even if its coefficient in a regression model is statistically insignificant and hence this decomposition technique resolves multicollinearity among covariates (Mishra, 2016) as well as the problem of an absence of variation in the values of a particular covariate. The approach also results in the sum of the individual Shapley-Owen contribution of each explanatory variable equalling the overall R-squared in the linear regression model (Mishra, 2016). This allows us to determine the relative contribution of each (set of) covariate(s).

This method is based on cooperative game theory with coalitions where regressors, as players of the game, "cooperate" to explain the variation in the dependent variable. To illustrate, in a 3-player game $(m=3)$, each player (say, player 1 ) can participate in 4 coalitions $(k=4)$ - where (a) 1 either features alone, implying $r=1$ and there is one such coalition ( $k=1$ ), (b) Player 1 features with one other member (two such 2-player coalitions are possible, one with Player 2 and the other with Player 3, hence $k=2$ and $r=2$ ), or (c) with two other members (one such 3-player coalition exists with both Players 2 and $3, r=3 ; k=1$ ). Player 1's contribution thus comes from 4 different coalitions. In each of the four coalitions, Player 1's contribution is computed as the difference in R-squared between a regression model that includes Player 1 and one that excludes Player 1 . These contributions are averaged first by the number of coalitions in an $r$-player coalition (by adding contributions for each $r$-player coalition and dividing by $k$ ) and then averaged across these three types of coalitions (i.e., by 3 , since $m=3$ ).

More generally, let $X(m)$ denote a set of $m$ explanatory variables in Equation (2), that estimates the relationship between empowerment related drivers of nutritional status of women. Let $X(p, r)$ and $X\left(p^{\prime}, r-1\right)$ be $r$ and $r$-1 member subsets of $X(m)$ with explanatory variable $X_{p}$ included in the former and excluded from the latter, respectively. Let the coefficient of determination of the respective sets be denoted by $R^{2}(p, r)$ and $R^{2}\left(p^{\prime}, r-1\right)$. Now, $X_{p}$ cooperates with the $m-1$ other regressors in Equation (2) in different coalitions of different sizes. Let $r \in[1, m]$ and represents the size of coalition in a game (referred to as an $r$-player game, or a regression with $r$ covariates); $k$ is the number of games evaluated for each group size $r$ in which the $p$ th player appears (a regression where covariate $X_{p}$ is present) and $c$ being each such case, 
so that $c$ runs from 1 to $k$ (Mishra, 2016). The individual contribution (Shapley-Owen contribution) of the explanatory variable $X_{p}$ is given by:

$$
S(t)=\frac{\sum_{r=1}^{m}\left\{\sum_{c=1}^{k}\left[R^{2}(p, r)-R^{2}\left(p^{\prime}, r-1\right)\right]_{c} / k\right\}}{m}
$$

The Shapley Owen contribution of each regressor is arrived at by estimating the difference in $\mathrm{R}^{2}$ across the paired models that include the variable of interest and then exclude it from the same model for every possible coalition involving this variable of interest, varying in sizes.

As a result - and in contrast to the Kitagawa-Blinder-Oaxaca decomposition - the Shapley-Owen values account for both the direct and synergistic contributions emerging from all possible coalitions between all players. The Shapley-Owen decomposition is especially useful in the context of understanding which aspects of a multidimensional concept like nutritional empowerment have the greatest influence on nutritional outcomes. This method can estimate the contribution of each domain-dimension cell of the WEN grid, but can also estimate the contribution of a specific variable representing a domain-dimension. In general, it factors in correlations between variables representing a specific domain-dimension as well as correlations across domain-dimensions. To illustrate, nutritional and health knowledge could be captured by a person's awareness of iodized salt and whether they know the main sources of calcium. It may be the case that knowledge of one is correlated with knowledge of the other and collective knowledge of both matters more than just either of them independently. Furthermore, nutritional knowledge is perhaps most effective when the person also has agency, resources, and a conducive institutional context (such as freedom of movement that enables market purchases of nutritious foods, etc.) to act upon the knowledge.

In this paper, we designate each cell or domain-dimension combination in the WEN Grid as one player in a coalition of all domain-dimensions and assess the relative contribution of each. A key feature of the Shapley-Owen decomposition technique is that it is possible to apportion fully, a domain-dimension's Shapley-Owen value to each constituent variable that represents the specific domain-dimension, a property called aggregation consistency (Israeli 2007). In this paper, we only identify the contribution of a specific domain-dimension and not the contribution of each domain-dimension's constituent elements, owing to space constraints. 


\subsection{Regression Framework}

To implement the Shapley-Owen decompositions, we first estimate model (3), below. It involves regressing the final nutritional outcomes (BMI and haemoglobin levels), $O$, on all the variables representing different domain-dimension elements of nutritional empowerment, including additional set of variables representing the overarching institutions and other relevant controls. ${ }^{6}$

$$
\begin{aligned}
& O=\delta_{0}+\delta_{F K} \text { Food }_{K}+\delta_{F R} \text { Food }_{F R}+\delta_{F A} \text { Food }_{A}+ \\
& \delta_{H K} \text { Health }_{K}+\delta_{H R} \text { Health }_{R}+\delta_{H A} \text { Health }_{A}+ \\
& \delta_{\text {FertK }} \text { Fert }_{K}+\delta_{\text {FertR }} \text { Fert }_{R}+\delta_{\text {Fert }_{A} \text { Fert }_{A}+}+ \\
& \delta_{I} \text { Inst }+\delta_{O C} O C+u
\end{aligned}
$$

In Equation (3), Food $(F)$, Health $(H)$ and Fert (Fert) are vectors of variables for different domains of nutritional empowerment and the subscripts $K, R, A$ refer to Knowledge, Resources and Agency, the dimensions of nutritional empowerment. Inst refers to Institutions and $O C$, other controls. Each of these domain-dimensions nests multiple variables that potentially interact with one another to jointly explain the variation in outcome variables. The list of variables covers most of the drivers of nutrition, as identified in the literature so far in the papers reviewed before. These are grouped into the different WEN domain-dimensions based on our mapping exercise and summarized (Table 3). In general, we do not construct variables that represent empowerment. Rather, we include variables as they are to minimize the subjectivity involved in the construct of measures. We also do not use a model selection strategy and choose instead to include all relevant variables that have been mapped to avoid specification searching. The number of variables we use in the estimation of Equation (3) in general exceeds the number of pertinent questions in a specific domain-dimension, presented in Figure 1, since we chose to include categorical variables as a set of multiple binary variables rather than converting this to a single indicator.

We use religion, social background, age, education levels of both husband and wife, ownership of house, marital and pregnancy status as other controls. Husband's education levels are available only for India-NFHS-3, India-NFHS-4 and BangladeshDHS. Ownership of house is available only for BIHS (Bangladesh). We expect that many of these characteristics will manifest in access to resources, agency, knowledge or all of

\footnotetext{
${ }^{6}$ In the conceptualization of nutritional empowerment, several intermediate outcomes were identified for each domain, such as dietary diversity, coping strategies, morbidity, birth spacing and parity, etc. However, in this paper, we focus only on the final outcomes.
} 
these. Our goal is restrict these controls to a minimal set to allow these attributes to express themselves via the WEN grid variables. We do not, for example, control for region, since systematic differences across regions in resource or infrastructure availability, would obscure the role of role of resources attributing it instead to region.

As mentioned, we focus on women in the age-group 15-49 years. We focus on rural populations where under-nutrition is pervasive and obesity continues to be less of a concern, accounting for between $2 \%$ to $5 \%$ of the sample in the six datasets covered (12.01\% to $24.15 \%$ if overweight is considered). We also study haemoglobin levels since iron-deficiency anemia is a serious public health concerns in South Asia, particularly in India and Bangladesh. We use only observations that have plausible values for BMI and anemia. $^{7}$

Using dataset-specific regression results from estimating Equation (3), we estimate Shapley-Owen values for each domain-dimension cell, the sum of which equals the R-squared of the estimated model. We also provide Shapley-Owen shares, which refer to the percentage of explained variation (i.e., R-squared) attributable to each domain-dimension cells. Since haemoglobin levels are available only for the Indian datasets, our analysis of haemoglobin is restricted to India. Regression results for each outcome, for each survey, are available in the online supplementary material and we do not interpret the statistical significance of each coefficient here, focussing instead on the Shapley-Owen shares.

\section{$5 \quad$ Results and Discussion}

India and Bangladesh fare poorly in health and nutritional outcomes, even though Bangladesh recorded a significant decline in child stunting and underweight figures over the last few decades and leapfrogged India (Table 4). Questions as to which factors of nutritional empowerment drive women's nutritional status in these countries are as yet not fully resolved. We first present findings from the Shapley-Owen decomposition for each domain-dimension of nutritional empowerment for six sets of regression for BMI and three for Haemoglobin levels in the Indian datasets.

7 The values of BMI range from 10 to 50. The values of haemoglobin levels range from 1 to 30 , both inclusive. 
Table 4: Selected summary statistics from NFHS-4 (India) and DHS (Bangladesh)

\begin{tabular}{|c|c|c|}
\hline & $\begin{array}{c}\text { India-NFHS- } \\
4(2015-2016)\end{array}$ & $\begin{array}{l}\text { Bangladesh } \\
\text { DHS(2014) }\end{array}$ \\
\hline \multicolumn{3}{|l|}{ Nutritional Status (\%) } \\
\hline Stunting $(<5$ years $)$ & 38.4 & 36.1 \\
\hline Severe stunting $(<5$ years $)$ & 16.3 & 11.6 \\
\hline Wasting $(<5$ years $)$ & 21.0 & 14.3 \\
\hline Severe Wasting $(<5$ years $)$ & 7.4 & 3.1 \\
\hline Undernourished women $(15-49$ years $)(B M I<18.5)$ & 22.9 & 18.6 \\
\hline \multicolumn{3}{|l|}{ Household with (\%) } \\
\hline Drinking water: improved source & 89.9 & 97.6 \\
\hline Sanitation : improved facility (not shared) & 48.4 & 45.0 \\
\hline Electricity & 88.2 & 73.0 \\
\hline Using solid fuel for cooking & 54.7 & 82.3 \\
\hline Television & 65.2 & 43.5 \\
\hline Refrigerator & 29.6 & 20.2 \\
\hline Motorcycle or Scooter & 37.7 & 6.4 \\
\hline \multicolumn{3}{|l|}{ Eligible women (15-49 years) (\%) } \\
\hline Secondary school or above & 35.7 & 45.9 \\
\hline Pre-natal care from trained/skilled provider & 79.3 & 63.9 \\
\hline Postnatal check up & 69.8 & 64.2 \\
\hline Knowledge: ovulation cycle and pregnancy & 17.5 & 24.2 \\
\hline Own/joint decision : spending her cash earnings & 82.1 & 85.6 \\
\hline
\end{tabular}

Source: Authors' calculations and NFHS-4 and DHS-2014 reports.The full set of summary statistics is available with the authors.

The variables included in the regression model (Equation 2) explain, on average a fifth of the total variation in BMI (ranging between 13.46\% of India-DLHS4 to $29.33 \%$ for Bangladesh-BIHS) - on par with existing studies on drivers of child nutrition. (Table 5).

Shapley-Owen decompositions underscore the overwhelming importance of Resources, which accounts, on average, for $50 \%$ and $41 \%$ of the total explained variation in BMI for India and Bangladesh, respectively (Figure 2). Among domains, Health is the most important contributor to BMI in India, while Food ranks highest in Bangladesh .

The domain of Food explains substantially more of the explained variation in BMI in Bangladesh (29\%) than in India (19\%), on average across datasets. We show later that this is not related to better coverage in the surveys. Within resources, HealthResource and Food-Resource together account for about 38\% of the explained variation 
in BMI, equivalent to around $7.8 \%$ of the total variation in BMI. The contribution of Health-Resources is larger for India than for Bangladesh. Interestingly, for BIHS (Bangladesh), Food Agency accounts for about 8\% of the total variation in BMI. HealthResource includes resources at the household level (access to improved water and sanitation facilities, availability of money to seek healthcare), village level (availability of transport facilities and condition of infrastructure like roads) and at the facility level (availability of doctors, medicines, among others). It also includes the type of work done by the individual, distinguishing manual from more sedentary occupations.

Three of the six surveys considered in the study come from the DHS family of surveys and hence have similar coverage of the WEN grid. This enables two kinds of comparisons (a) change in key nutritional empowerment related drivers of BMI for India between India-NFHS-3 (2005) and India-NFHS-4 (2015) and (b) a comparison of key drivers of BMI in India-NFHS-4 (2015) and Bangladesh-DHS (2014).

For India, both in 2005 and 2015, Resources explains 40\% to 50\% of the total explained variation in BMI, higher in the more recent survey (Table 5). In both India and Bangladesh, variables representing nutritional empowerment and other controls explain about $19 \%$ of the total variation in BMI. In both countries, Resources matter most, accounting for almost half of all the explained variation in BMI. Health-Resources in particular appears to be critical, more so for India than for Bangladesh. Remarkably, despite well-documented differences in policy attention in the two countries, the key empowerment related drivers of nutrition appear to be similar suggesting that across contexts Health-Resources might be a crucial driver of women's nutrition.

For haemoglobin, elements of the WEN grid explain almost $7 \%$ of its total variation, which is consistent with the empirical research on anemia in India. Even more than with BMI, Resources are overwhelmingly important and among domains both Health and Fertility are key influences (Figure 3; Table 6). Health and Fertility Resources account for $27 \%$ to $62 \%$ of the explained variation in the Indian dataset. 
Figure 2 : Contribution of dimensions of nutritional empowerment to explained variation in BMI and haemoglobin levels (averaged across all surveys)

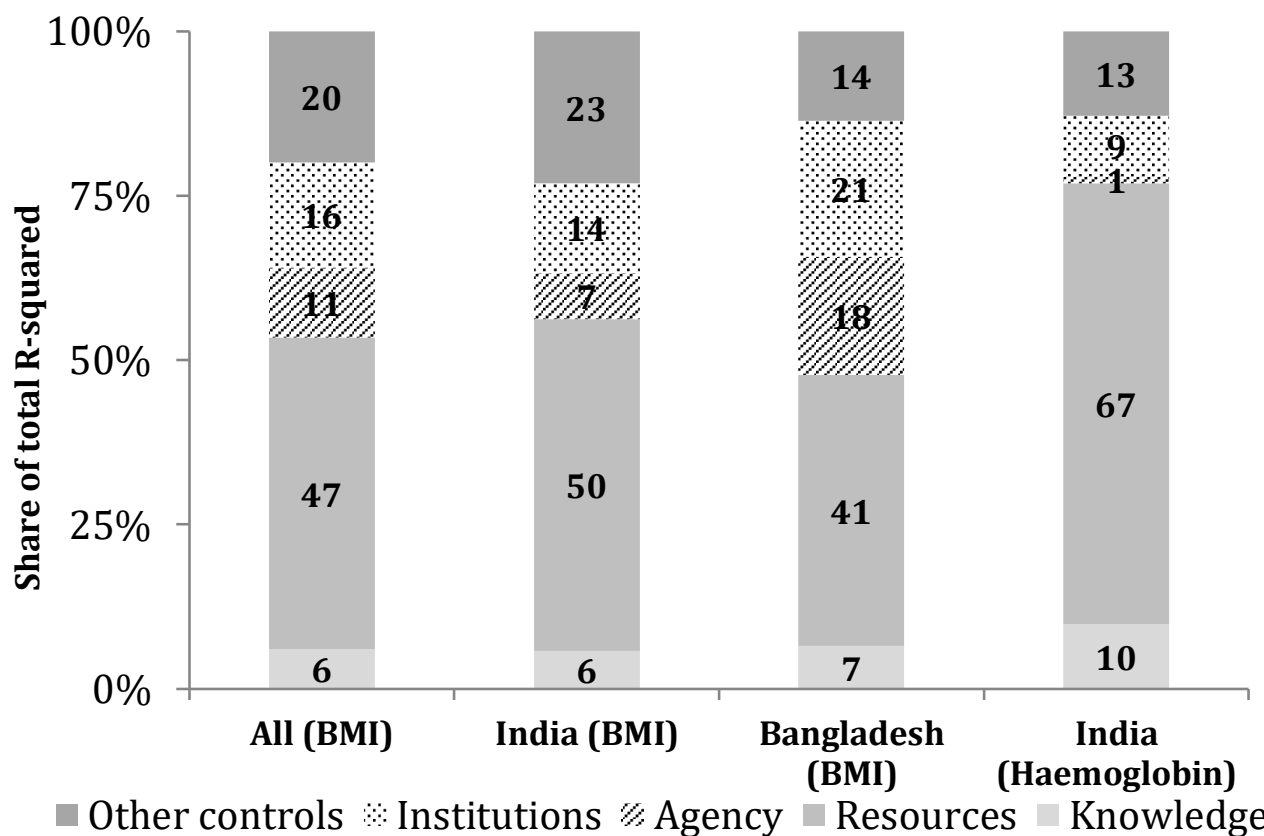

Figure 3 : Contribution of domains of nutritional empowerment to explained variation in BMI and haemoglobin levels (averaged across all surveys)

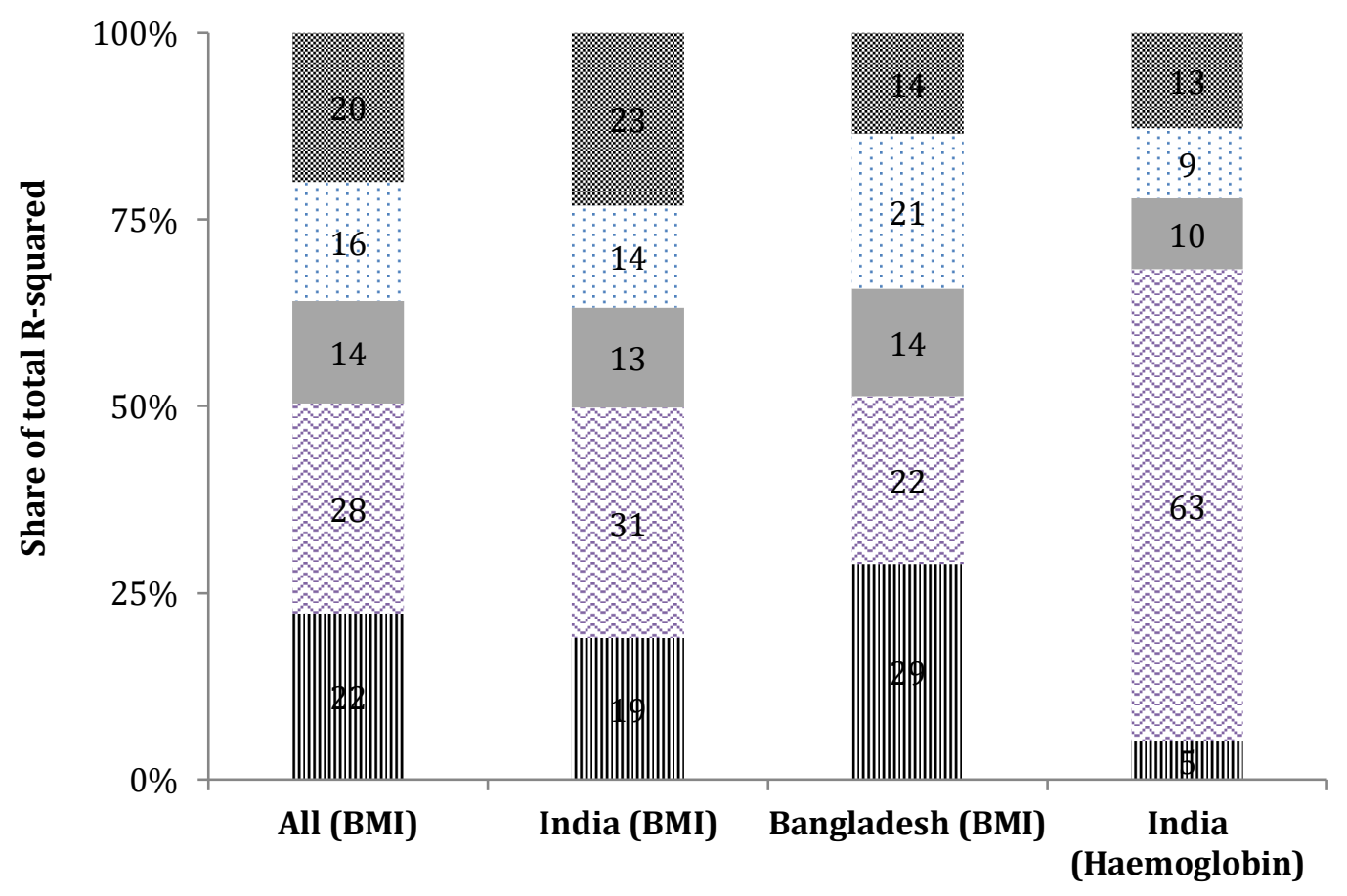

Other controls Institutions $\quad$ Fertility $\approx$ Health $\quad$ IIII Food 
Figure 4: The relative contribution of domain-dimensions of nutritional empowerment to explained variation in BMI, India-NFHS-4

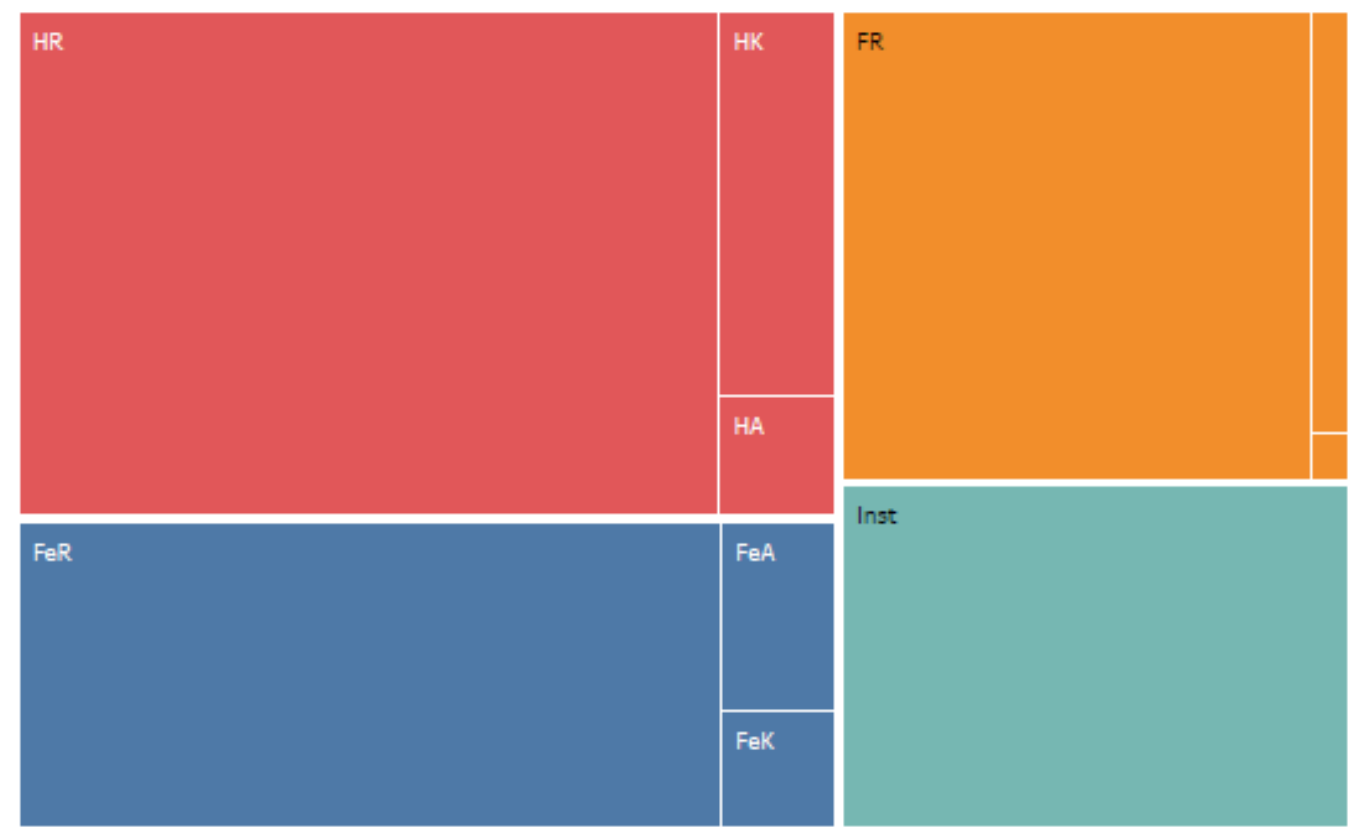

Note: FK-Food Knowledge, FR-Food Resource, FA-Food Agency, HK-Health Knowledge, HR-Health Resource, HA-Health Agency, FeK-Fertility Knowledge, FeR-Fertility Resource, FeA-Fertility Agency, Inst-Institutions. Color of the tree diagram reflects domains of the WEN grid. Size shows Shapley-Owen shares of each cell of the WEN grid. For Food domain, dimensions of Agency (1.07\%) and Knowledge (0.12\%) have negligible contribution and hence no labels.

Figure 5: The relative contribution of domain-dimensions of nutritional empowerment to explained variation in BMI, DHS (Bangladesh)

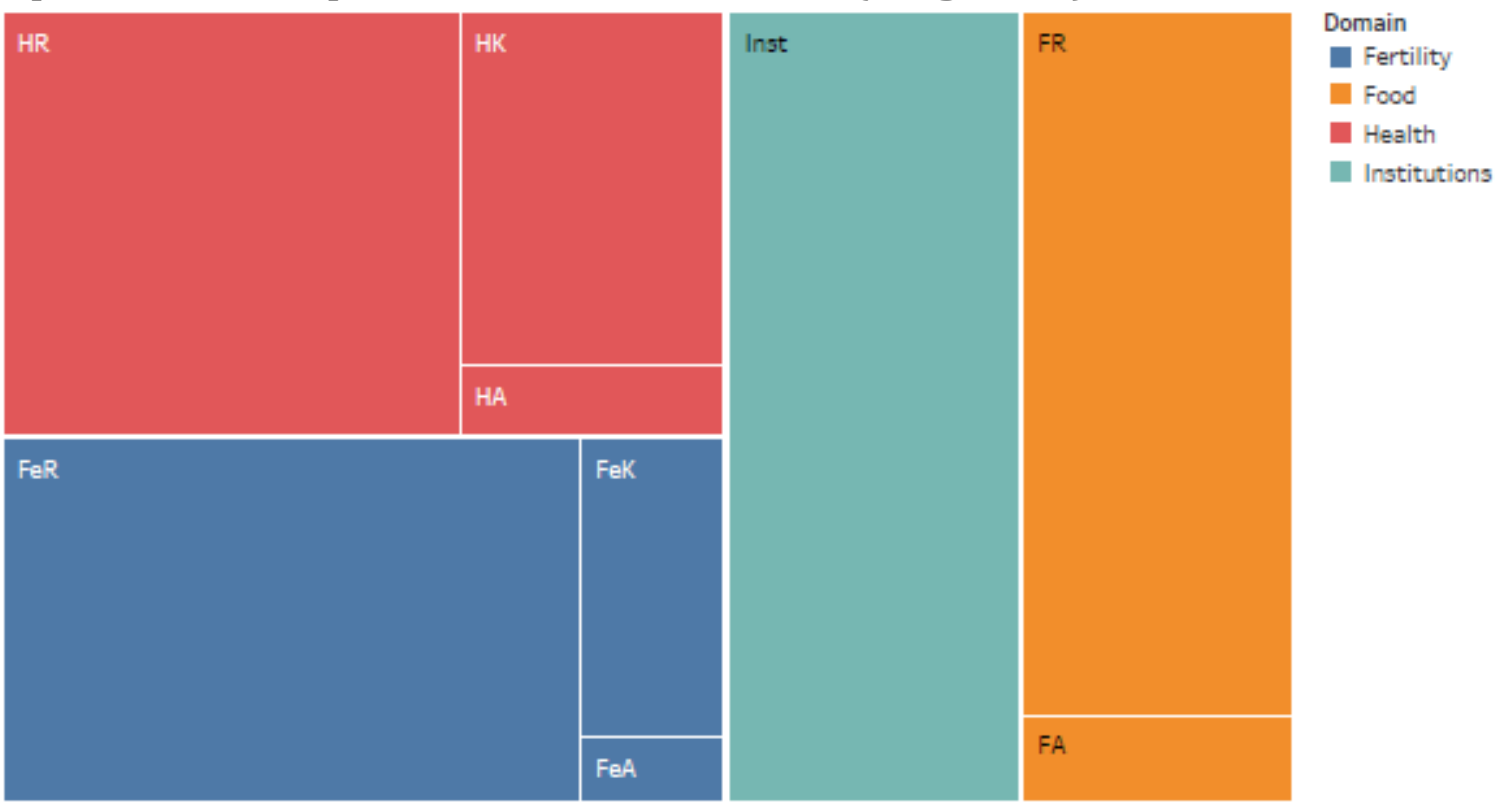

Note: FK-Food Knowledge, FR-Food Resource, FA-Food Agency, HK-Health Knowledge, HR-Health Resource, HA-Health Agency, FeK-Fertility Knowledge, FeR-Fertility Resource, FeA-Fertility Agency, Inst-Institutions. Color of the tree diagram reflects domains of the WEN grid. Size shows Shapley-Owen shares of each cell of the WEN grid.

Source: Based on authors' calculations 
Table 5: Shapley-Owen decomposition for BMI

\begin{tabular}{|c|c|c|c|c|c|c|c|c|c|c|c|c|c|}
\hline \multirow{2}{*}{ S.No } & \multirow{2}{*}{$\begin{array}{l}\text { Domain- } \\
\text { Dimension }\end{array}$} & \multicolumn{2}{|c|}{$\begin{array}{c}\text { India-NFHS-3 } \\
2005-06\end{array}$} & \multicolumn{2}{|c|}{$\begin{array}{c}\text { India-NFHS-4 } \\
2014-2015\end{array}$} & \multicolumn{2}{|c|}{$\begin{array}{c}\text { India-DLHS-4 } \\
2012-2013\end{array}$} & \multicolumn{2}{|c|}{$\begin{array}{c}\text { IHDS } 2 \text { (India) } \\
2011-12\end{array}$} & \multicolumn{2}{|c|}{$\begin{array}{c}\text { Bangladesh-DHS } \\
2014\end{array}$} & \multicolumn{2}{|c|}{$\begin{array}{c}\text { BIHS (Bangladesh) } \\
2015\end{array}$} \\
\hline & & $\begin{array}{c}\text { Shapley- } \\
\text { Owen } \\
\text { value } \\
\end{array}$ & Percent & $\begin{array}{c}\text { Shapley- } \\
\text { Owen } \\
\text { value }\end{array}$ & Percent & $\begin{array}{c}\text { Shapley- } \\
\text { Owen } \\
\text { value } \\
\end{array}$ & Percent & $\begin{array}{c}\text { Shapley- } \\
\text { Owen } \\
\text { value } \\
\end{array}$ & Percent & $\begin{array}{c}\text { Shapley- } \\
\text { Owen } \\
\text { value } \\
\end{array}$ & Percent & $\begin{array}{c}\text { Shapley- } \\
\text { Owen } \\
\text { value } \\
\end{array}$ & Percent \\
\hline & R-squared & \multicolumn{2}{|c|}{0.2080} & \multicolumn{2}{|c|}{0.1944} & \multicolumn{2}{|c|}{0.1346} & \multicolumn{2}{|c|}{0.2203} & \multicolumn{2}{|c|}{0.1807} & \multicolumn{2}{|c|}{0.2933} \\
\hline 1 & $\begin{array}{l}\text { Food } \\
\text { Knowledge }\end{array}$ & 0.0008 & 0.39 & 0.0002 & 0.12 & NA & NA & NA & NA & NA & NA & NA & NA \\
\hline 2 & $\begin{array}{l}\text { Food } \\
\text { Resource } \\
\end{array}$ & 0.0337 & 16.22 & 0.0287 & 14.77 & 0.0232 & 17.23 & 0.0456 & 20.69 & 0.0272 & 15.04 & 0.0427 & 14.55 \\
\hline 3 & $\begin{array}{l}\text { Food } \\
\text { Agency }\end{array}$ & 0.0061 & 2.93 & 0.0021 & 1.07 & NA & NA & 0.0051 & 2.31 & 0.0034 & 1.86 & 0.0771 & 26.3 \\
\hline 4 & $\begin{array}{l}\text { Health } \\
\text { Knowledge }\end{array}$ & 0.0104 & 5.00 & 0.0058 & 3.00 & 0.0028 & 2.06 & 0.0102 & 4.64 & 0.0134 & 7.43 & 0.0031 & 1.07 \\
\hline 5 & $\begin{array}{l}\text { Health } \\
\text { Resource }\end{array}$ & 0.0370 & 17.78 & 0.0460 & 23.64 & 0.0406 & 30.19 & 0.0572 & 25.96 & 0.0276 & 15.26 & 0.0497 & 16.95 \\
\hline 6 & $\begin{array}{l}\text { Health } \\
\text { Agency }\end{array}$ & 0.0063 & 3.03 & 0.0018 & 0.94 & 0.0009 & 0.67 & 0.0147 & 6.65 & 0.0026 & 1.43 & 0.0082 & 2.81 \\
\hline 7 & $\begin{array}{l}\text { Fertility } \\
\text { Knowledge }\end{array}$ & 0.0005 & 0.23 & 0.0018 & 0.93 & 0.0079 & 5.84 & 0.0025 & 1.15 & 0.0061 & 3.39 & 0.0038 & 1.31 \\
\hline 8 & $\begin{array}{l}\text { Fertility } \\
\text { Resource } \\
\end{array}$ & 0.0147 & 7.06 & 0.0282 & 14.52 & 0.0072 & 5.34 & 0.0182 & 8.24 & 0.0301 & 16.66 & 0.0109 & 3.7 \\
\hline 9 & $\begin{array}{l}\text { Fertility } \\
\text { Agency }\end{array}$ & 0.0063 & 3.02 & 0.0029 & 1.47 & 0.0010 & 0.75 & 0.0112 & 5.06 & 0.0014 & 0.77 & 0.0086 & 2.94 \\
\hline 10 & Institutions & 0.0350 & 16.83 & 0.0228 & 11.74 & 0.0138 & 10.26 & 0.0347 & 15.74 & 0.0329 & 18.2 & 0.0679 & 23.15 \\
\hline 11 & $\begin{array}{l}\begin{array}{l}\text { Other } \\
\text { controls }\end{array} \\
\end{array}$ & 0.0572 & 27.50 & 0.0539 & 27.73 & 0.0372 & 27.66 & 0.0211 & 9.55 & 0.0360 & 19.95 & 0.0211 & 7.19 \\
\hline \multicolumn{2}{|c|}{ Observations } & \multicolumn{2}{|c|}{65575} & 22 & & \multicolumn{2}{|c|}{160299} & \multicolumn{2}{|c|}{25337} & \multicolumn{2}{|c|}{11598} & \multicolumn{2}{|c|}{5051} \\
\hline \multicolumn{2}{|c|}{$\begin{array}{l}\text { Number of variables in } \\
\text { the regression }\end{array}$} & \multicolumn{2}{|c|}{367} & \multicolumn{2}{|c|}{379} & \multicolumn{2}{|c|}{447} & \multicolumn{2}{|c|}{470} & \multicolumn{2}{|c|}{233} & \multicolumn{2}{|c|}{555} \\
\hline
\end{tabular}

Source: Author's calculations 
Table 6: Shapley-Owen decomposition for haemoglobin level

\begin{tabular}{|c|c|c|c|c|c|c|c|}
\hline \multirow[b]{2}{*}{ S.No } & \multirow[b]{2}{*}{$\begin{array}{l}\text { Domain- } \\
\text { Dimension }\end{array}$} & \multicolumn{2}{|c|}{$\begin{array}{c}\text { India-NFHS-3 } \\
2005-06\end{array}$} & \multicolumn{2}{|c|}{$\begin{array}{c}\text { India-NFHS-4 } \\
2014-2015\end{array}$} & \multicolumn{2}{|c|}{$\begin{array}{c}\text { India-DLHS-4 } \\
2012-2013\end{array}$} \\
\hline & & $\begin{array}{c}\text { Shapley- } \\
\text { Owen } \\
\text { value }\end{array}$ & Percent & $\begin{array}{c}\text { Shapley- } \\
\text { Owen } \\
\text { value }\end{array}$ & Percent & $\begin{array}{c}\text { Shapley- } \\
\text { Owen value }\end{array}$ & Percent \\
\hline & R-squared & \multicolumn{2}{|c|}{0.0677} & \multicolumn{2}{|c|}{0.0717} & \multicolumn{2}{|c|}{0.0583} \\
\hline 1 & Food Knowledge & 0.0002 & 0.24 & 0.0001 & 0.10 & NA & NA \\
\hline 2 & Food Resource & 0.0061 & 8.96 & 0.0045 & 6.23 & 0.0030 & 5.20 \\
\hline 3 & Food Agency & 0.0012 & 1.70 & 0.0010 & 1.42 & NA & NA \\
\hline 4 & $\begin{array}{l}\text { Health } \\
\text { Knowledge }\end{array}$ & 0.0049 & 7.18 & 0.0013 & 1.86 & 0.0032 & 5.49 \\
\hline 5 & Health Resource & 0.0101 & 14.95 & 0.0128 & 17.82 & 0.0334 & 57.34 \\
\hline 6 & Health Agency & 0.0013 & 1.89 & 0.0006 & 0.78 & 0.0002 & 0.29 \\
\hline 7 & $\begin{array}{l}\text { Fertility } \\
\text { Knowledge }\end{array}$ & 0.0005 & 0.78 & 0.0017 & 2.39 & 0.0026 & 4.42 \\
\hline 8 & $\begin{array}{l}\text { Fertility } \\
\text { Resource }\end{array}$ & 0.0079 & 11.68 & 0.0154 & 21.52 & 0.0026 & 4.40 \\
\hline 9 & Fertility Agency & 0.0039 & 5.78 & 0.0081 & 11.25 & 0.0004 & 0.73 \\
\hline 10 & Institutions & 0.0086 & 12.62 & 0.0047 & 6.49 & 0.0054 & 9.32 \\
\hline 11 & Other controls & 0.0230 & 33.97 & 0.0216 & 30.10 & 0.0075 & 12.81 \\
\hline \multicolumn{2}{|c|}{ Observations } & \multicolumn{2}{|c|}{62901} & \multicolumn{2}{|c|}{22817} & \multicolumn{2}{|c|}{153743} \\
\hline \multicolumn{2}{|c|}{$\begin{array}{l}\text { Number of variables in the } \\
\text { regression }\end{array}$} & \multicolumn{2}{|c|}{366} & \multicolumn{2}{|c|}{378} & \multicolumn{2}{|c|}{448} \\
\hline
\end{tabular}

Source: Author's calculations.

In the literature on gender and nutrition, women's empowerment is often proxied by variables representing agency (having a say or voice in decision making), ownership and control over assets, or to generic variables such as women's education and institutional factors such as freedom of movement (Donald et al., 2018). Our findings suggest that Resources, particularly in the domain of health, constitute a crucial dimension of nutritional empowerment that drives women's nutritional status, rather than Agency. There are two ways to understand this result. First, it is possible that, in highly resource constrained settings, women are forced to use their agency and knowledge in creative ways to procure what resources they can. Thus, where resources (and its influence on nutritional status) are limited, the contribution of knowledge and fertility might be higher. In this case, the correlation between the contribution of Knowledge and Agency on the one hand and Resources, on the other, would be negative and that they act as substitutes. Second, it could be the case that Knowledge and Agency can only contribute when there exists adequate Resources are available and matter. In this case, Agency and Knowledge complement Resources and would hence be correlated positively. 
We find evidence of the latter. The Shapley contribution of Resource is moderately positively correlated with dimensions of Knowledge (0.41) and Agency (0.31) suggesting that when Resources are available and influence nutritional outcomes, Knowledge and Agency too are likely to explain more of the variation in the nutritional status of women. Alternatively, when Knowledge and Agency are absent and hence do not influence nutritional status greatly, Resources too appear to have only a limited role.

To rule out the possibility that a high Shapley-Owen value for Resources is spurious and not on account of better coverage of Resource in these surveys, we plot the Shapley values/shares of each domain-dimension against the number of questions in each domain-dimension. Figure 6 suggests that the correlation between the two is 0.31 , underscoring that the Shapley-Owen contributions relates positively to the number of questions, but not strongly. In fact, we also find that the Shapley-Owen value per question in each domain-dimension and the number of questions for that domaindimension are moderately negatively correlated (-0.37; Figure 7). Here too, it is not the case that more questions boost Shapley-Owen values and the appropriateness of the question may matter more.

We recognize, however, that the Shapley-Owen decomposition exercise is only as good as the effectiveness of surveys in capturing aspects of nutritional empowerment. This remains a limitation of our exercise and points to the value of efforts to carefully conceptualize nutritional empowerment and to designing purpose-built surveys to capture nutritional empowerment comprehensively. Some of the surveys analysed better captured the constraints and opportunities women face regarding their own nutritional status. In the case of NFHS, for example, it had relevant questions on foodrelated agency that were missing in other surveys. 
Figure 6: Shapley-Owen values versus survey coverage of domain-dimensions

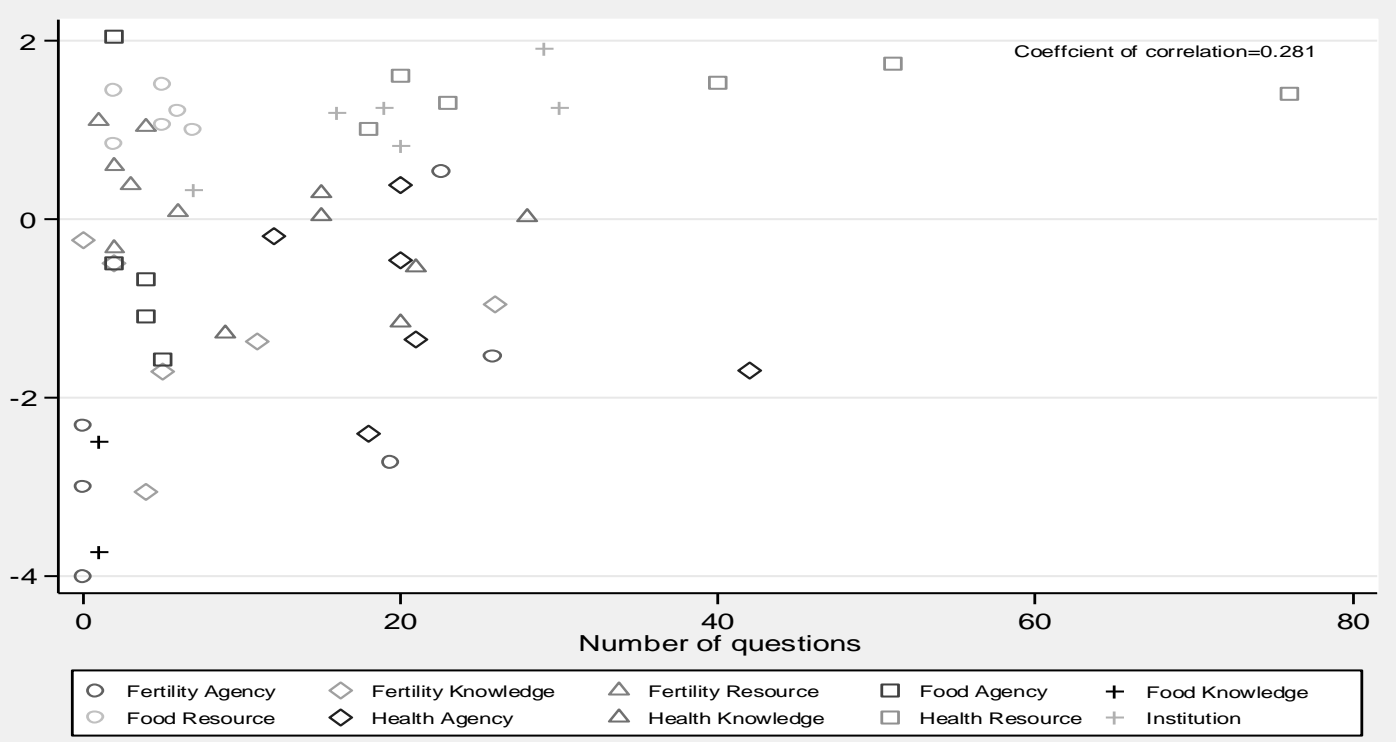

Source: Based on authors' calculations

Figure 7: Shapley-Owen values per question versus survey coverage of domaindimensions

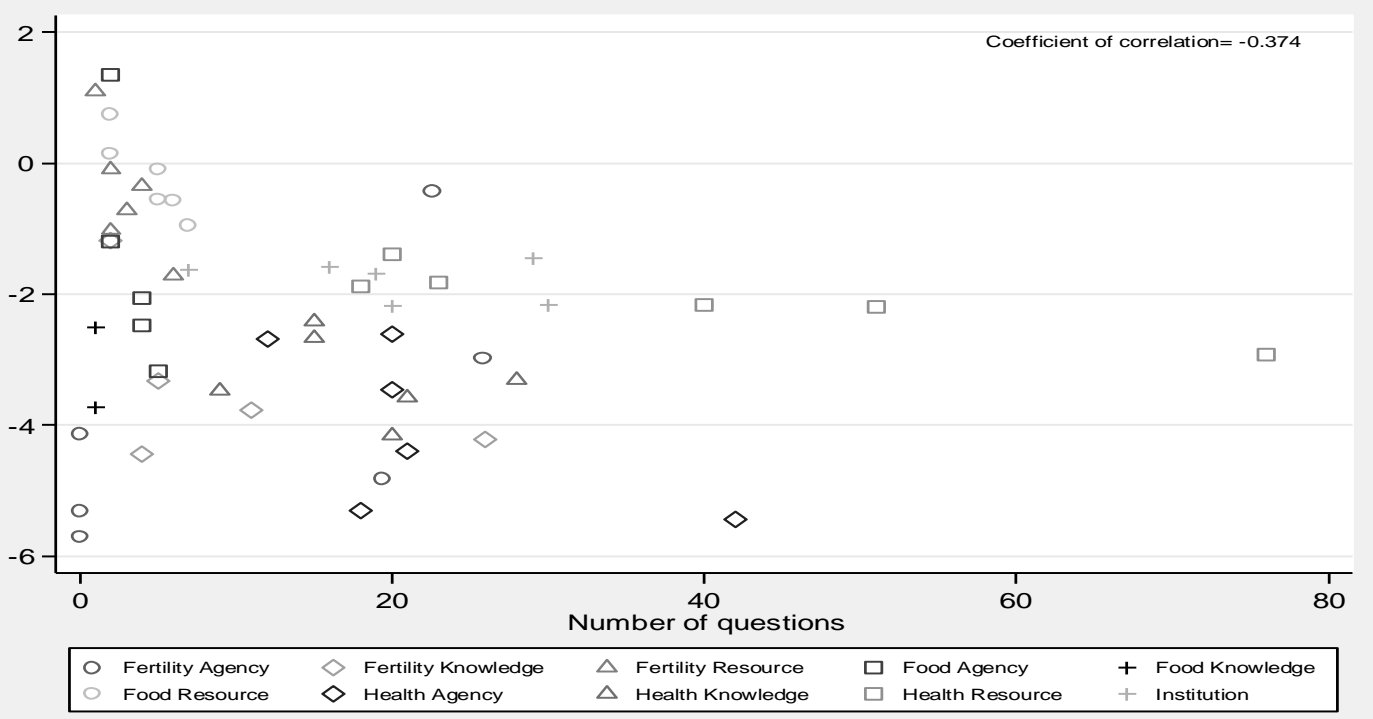

Source: Based on authors' calculations 


\section{Concluding Remarks}

In this paper, we analysed six widely used surveys from India and Bangladesh and use the concept of nutritional empowerment to demonstrate the value of the Shapley-Owen decomposition technique - this technique allows us to evaluate which aspects of nutritional empowerment are most relevant for women's nutritional outcomes. This is a valuable intervention because other approaches fail to account for interactions among covariates, which means mis-specifying the relative importance of each covariate in driving nutritional outcomes.

Our work suggests that Resources play a powerful role and Knowledge and Agency are perhaps more likely to be complementary factors, rather than substitutes for Resources. Policies focussing on women's empowerment must therefore not focus merely on providing knowledge or seek to strengthen their decision-making roles in the family. They must prioritize ensuring that health resources are available to women in constrained settings and promoting effective technologies to reduce their work burden. The importance of resources also resonates with the view that the positive relationship between economic growth and nutrition is perhaps driven by an expansion in access to resources for women. This suggests that where economic growth fails to expand resources, the state would do well to focus funding and policies toward enabling women to access appropriate, affordable and quality health and food resources.

Future research that applies the Shapley-Owen decomposition to a more complete account of all aspects of nutritional empowerment could inform researchers and policymakers about the relative merit of other aspects of nutritional empowerment not well covered in the surveys studies here. Special surveys that are better equipped to capture nutritional empowerment would enable us to more accurately assess the aspects of women's empowerment that influence their nutritional status, or for that matter, of their children's. It would also be interesting to decompose these contributions even further, to find out for example, which specific factor is responsible for the overwhelming importance of Health resources. Such findings could assist in identifying key areas of policy intervention and actionable policy variables. 


\section{References}

Alkire, S., Meinzen-Dick, R., Peterman, A., Quisumbing, A., Seymour, G. \& Vaz, A., (2013).The women's empowerment in agriculture index. World Development, 52, 71-91.

Behrman, J. R., \& Wolfe, B. L. (1987). How does mother's schooling affect family health, nutrition, medical care usage, and household sanitation? Journal of econometrics, 36(12), $185-204$.

Bhagowalia, P., Kadiyala, S., \& Headey, D. (2012). Agriculture, income and nutrition linkages in India: Insights from a nationally representative survey. IFPRI Discussion Paper 01195.

Black, R.E., Allen, L.H., Bhutta, Z.A., Caulfield, L.E., De Onis, M., Ezzati, Maternal \& Child Undernutrition Study Group (2008). Maternal and child undernutrition: global and regional exposures and health consequences. The lancet, 371(9608), 243-260.

Black, R.E., Victora, C.G., Walker, S.P., Bhutta, Z.A., Christian, P., De Onis, M.,..Uauy, R. (2013). Maternal and child undernutrition and overweight in low-income and middleincome countries. The lancet, 382(9890), 427-451.

Cavatorta, E., Shankar, B. \& Flores-Martinez, A. (2015).Explaining cross-state disparities in child nutrition in rural India. World Development, 76, 216-237.

CIRCUS (2006). Focus on Children under Six, Citizens' Initiative for the Rights of Children under Six, New-Delhi.

Coffey, D., Khera, R., \& Spears, D. (2013). Women's Status and Children's Height in India: Evidence from Rural Joint Households. Princeton University working paper.

Cunningham, K., Ruel, M., Ferguson, E. \& Uauy, R. (2015). Women's empowerment and child nutritional status in South Asia: a synthesis of the literature. Maternal \& child nutrition, 11(1), 1-19.

Desai, S., \& Thorat, A., (2013). Beyond the great Indian nutrition debate. Economic \& Political Weekly, 16, 45-46.

Donald, A., Koolwal, G., Annan, J., Falb, K., \& Goldstein, M. (2017). Measuring women's agency. World Bank Policy Research Working Paper 8148.

Doss, C., Kieran,C., \& Kilic, T. (2017). Measuring ownership, control, and use of assets. World Bank Policy Research Working Paper 8146.

FAO, IFAD, UNICEF, WFP \& WHO. (2017), 'The State of Food Security and Nutrition in the World: Building resilience for peace and food security', Rome, FAO.

Gillespie, S., \& Kadiyala, S. (2012). Exploring the agriculture-nutrition disconnect in India. Reshaping agriculture for nutrition and health. Washington DC, International Food Policy Research Institute, 173-182.

Headey, D. (2013). Developmental drivers of nutritional change: A cross- country analysis. World Development, 42, 76-88. 
Headey, D., Hoddinott, J., Ali, D., Tesfaye, R., \& Dereje, M. (2015). The other Asian enigma: explaining the rapid reduction of undernutrition in Bangladesh. World Development, 66, 749-761.

Headey D., Hoddinott J., \& Park S. (2016). Drivers of nutritional change in four South Asian countries: a dynamic observational analysis. Maternal Child Nutrition, 12, 210-8.

Headey, D., Hoddinott, J., \& Park, S. (2017). Accounting for nutritional changes in six success stories: A regression-decomposition approach. Global Food Security, 13, 12-20.

Huettner, F., \& Sunder, M. (2012).Axiomatic arguments for decomposing goodness of fit according to Shapley and Owen values. Electronic Journal of Statistics, 6, 1239-1250.

Israeli, 0. (2007). A Shapley-based decomposition of the R-square of a linear regression. The Journal of Economic Inequality, 5(2), 199-212.

Jayachandran, S., \& Pande, R. (2013). Choice not genes: Probable cause for the IndiaAfrica child height gap. Economic and Political Weekly, 48(34), 77-79.

Kabeer, N. (1999a). Resources, agency, achievements: Reflections on the measurement of women's empowerment. Development and change, 30(3), 435-464.

Kadiyala, S., Harris, J., Headey, D., Yosef, S., \& Gillespie, S. (2014). Agriculture and nutrition in India: mapping evidence to pathways. Annals of the New York Academy of Sciences, 1331(1), 43-56.

Kim, R., Mejía-Guevara, I., Corsi, D. J., Aguayo, V. M., \& Subramanian, S. V. (2017). Relative importance of 13 correlates of child stunting in South Asia: insights from nationally representative data from Afghanistan, Bangladesh, India, Nepal, and Pakistan. Social Science \& Medicine, 187, 144-154.

Lentz, E., Narayanan, S., \& De, A. (2018). Last and least: Findings on intra-household under-nutrition from participatory research in South Asia (under review)

Malapit, H.J.L., \& Quisumbing, A.R. (2015). What dimensions of women's empowerment in agriculture matter for nutrition in Ghana? Food Policy, 52, 54-63.

Malapit, H.J.L., Kadiyala, S., Quisumbing, A.R., Cunningham, K. \& Tyagi, P. (2015). Women's empowerment mitigates the negative effects of low production diversity on maternal and child nutrition in Nepal. The Journal of Development Studies, 51(8), 1097 1123.

Menon, P., Headey, D., Avula, R., \& Nguyen, P. H. (2018). Understanding the geographical burden of stunting in India: A regression-decomposition analysis of district-level data from the 2015-16. Maternal \& Child Nutrition, e12620.

Miedema, S. S., Haardörfer, R., Girard, A. W., \& Yount, K. M. (2018). Women's empowerment in East Africa: Development of a cross-country comparable measure. World Development, 110, 453-464.

Mishra, S.K., (2016). Shapley Value Regression and the Resolution of Multicollinearity. Journal of Economics Bibliography, 3(3), 498-515. 
Narayanan, S., Fontana, M., Lentz, E., \& Kulkarni, B. (2017a). Rural women's empowerment in nutrition: a proposal for diagnostics linking food, health and institution, Background Paper for UN Women Commission on the Status of Women 62.

Nguyen, P.H., Headey, D., Frongillo, E.A., Tran, L.M., Rawat, R., Ruel, M.T. \& Menon, P. (2017). Changes in Underlying Determinants Explain Rapid Increases in Child Linear Growth in Alive \& Thrive Study Areas between 2010 and 2014 in Bangladesh and Vietnam. The Journal of Nutrition, 147(3), 462-469.

Pratley, P. (2016). Associations between quantitative measures of women's empowerment and access to care and health status for mothers and their children: A systematic review of evidence from the developing world. Social Science \& Medicine, 169, 119-131.

Quisumbing, A. R., \& Maluccio, J. A. (2003). Resources at marriage and intrahousehold allocation: Evidence from Bangladesh, Ethiopia, Indonesia, and South Africa. Oxford Bulletin of Economics and Statistics, 65(3), 283-327.

Ramalingaswami, V., Jonsson, U., \& Rohde, J. (1997). Malnutrition: a South Asian enigma. In Malnutrition in South Asia: A Regional Profile. Rosa Publication no. 5, 1121.Kathmandu: UNICEF Regional Office for South Asia.

Ruel, M.T., \& Alderman, H. (2013). Nutrition-sensitive interventions and programmes: how can they help to accelerate progress in improving maternal and child nutrition? The Lancet, 382(9891), 536-551.

Sharaf M.F., \& Rashad A.S. (2016). Regional inequalities in child malnutrition in Egypt, Jordan, and Yemen: a Blinder-Oaxaca decomposition analysis. Health Econ Rev, 6, 23.

Sinharoy, S. S., Waid, J. L., Haardörfer, R., Wendt, A., Gabrysch, S., \&Yount, K. M. (2018). Women's dietary diversity in rural Bangladesh: Pathways through women's empowerment. Maternal \& child nutrition, 14(1).

Smith, L. C., Ramakrishnan, U., Ndiaye, A., Haddad, L., \& Martorell, R. (2003). The Importance of Women's Status for Child Nutrition in Developing Countries: International Food Policy Research Institute (IFPRI) Research Report Abstract 131. Food and Nutrition Bulletin, 24(3), 287-288.

Sraboni, E., Malapit, H.J., Quisumbing, A.R. \& Ahmed, A.U. (2014). Women's empowerment in agriculture: What role for food security in Bangladesh? World Development, 61, 11-52.

Srinivasan, C.S., Zanello, G., \& Shankar B. (2013) Rural-urban disparities in child nutrition in Bangladesh and Nepal. BMC Public Health, 13, 581.

UNICEF (1990).Strategy for improved nutrition of children and women in developing countries.UNICEF Policy Review 1990-1 (E/ICEF/1990/ L.6). New York: UNICEF

van den Bold, M., Quisumbing, A. R., \& Gillespie, S. (2013). Women's empowerment and nutrition: An evidence review. IFPRI Discussion Paper 1294.

World Bank (2018). All Hands on Deck: Reducing stunting through multi-sectoral efforts in Sub-Saharan Africa. Washington, D.C. , World Bank Group. 


\subsection{Appendix Table 1: Decomposition methods}

\begin{tabular}{|c|c|c|c|c|}
\hline & Method & $\begin{array}{l}\text { Empirical } \\
\text { Studies }\end{array}$ & Study details & Findings \\
\hline \multirow[t]{2}{*}{1} & \multirow[t]{2}{*}{$\begin{array}{l}\text { Correlational } \\
\text { Analysis }\end{array}$} & Kim et al., 2017 & $\begin{array}{l}\text { - Nationally representative } \\
\text { sample from DHS family } \\
\text { (Bangladesh-2014, India- } \\
2005 \text {, Nepal-2011, } \\
\text { Pakistan-2013) and } \\
\text { National Nutrition Survey } \\
\text { (Afghanistan-2013) } \\
\text {-HAZ scores for children in } \\
\text { two age groups, 6-8 } \\
\text { months }(3,159) \text { and } 6-23 \\
\text { months }(18,586) \\
\text {-13 correlates selected on } \\
\text { basis of multi-factorial } \\
\text { framework that consider } \\
\text { various risk factors } \\
\text {-Logistical regression }\end{array}$ & $\begin{array}{l}\text { Maternal } \\
\text { characteristics (BMI, } \\
\text { Height), household } \\
\text { wealth, minimum } \\
\text { diet diversity are } \\
\text { strong determinants } \\
\text { of stunting in } \\
\text { children }\end{array}$ \\
\hline & & $\begin{array}{l}\text { Bhagowaliaet al., } \\
2012\end{array}$ & $\begin{array}{l}\text {-Nationally representative } \\
\text { data for India from } 34 \\
\text { states, } 570 \text { districts of } \\
\text { India (IHDS-2005). } \\
\text {-HAZ and WHZ scores of } \\
19,000 \text { children aged [0-5] } \\
\text { years } \\
\text {-Correlates include } \\
\text { proxies for caregiver } \\
\text { resources and knowledge, } \\
\text { food security, access to } \\
\text { healthcare, sanitation and } \\
\text { water supply } \\
\text {-OLS regression }\end{array}$ & $\begin{array}{l}\text { Female's secondary } \\
\text { education, access to } \\
\text { safe water and } \\
\text { sanitation facilities, } \\
\text { vaccinations and } \\
\text { ante-natal check-ups } \\
\text { are significant } \\
\text { determinants of } \\
\text { under-nutrition for } \\
\text { Indian children }\end{array}$ \\
\hline 2 & $\begin{array}{l}\text { Data Reduction } \\
\text { Techniques and } \\
\text { Regression } \\
\text { Analysis }\end{array}$ & $\begin{array}{l}\text { Malapitet al., } \\
\text { 2015a }\end{array}$ & $\begin{array}{l}\text {-2012 baseline data on } \\
\text { Feed the Future's zone of } \\
\text { influence in Northern } \\
\text { Ghana } \\
\text {-HAZ, WHZ, dietary } \\
\text { diversity scores for 1,437 } \\
\text { children [0-5 years] and } \\
\text { diet diversity scores and } \\
\text { BMI for 2,027 women [15- } \\
\text { 49] } \\
\text {-Correlates from different } \\
\text { domains and Gender } \\
\text { Parity Index of the } \\
\text { Women's Empowerment }\end{array}$ & $\begin{array}{l}\text { Women's } \\
\text { empowerment } \\
\text { (WEAI) strongly } \\
\text { associated with } \\
\text { child's feeding } \\
\text { practices but not } \\
\text { with their nutritional } \\
\text { status.Different } \\
\text { domains of women's } \\
\text { empowerment } \\
\text { matter of women's } \\
\text { and children's } \\
\text { nutritional outcomes }\end{array}$ \\
\hline
\end{tabular}




\begin{tabular}{|c|c|c|c|c|}
\hline & Method & $\begin{array}{l}\text { Empirical } \\
\text { Studies }\end{array}$ & Study details & Findings \\
\hline & & & $\begin{array}{l}\text { in Agriculture Index } \\
\text { (WEAI) } \\
\text { - OLS regression }\end{array}$ & \\
\hline & & $\begin{array}{l}\text { Malapitet al., } \\
2015 \mathrm{~b}\end{array}$ & $\begin{array}{l}\text {--USAID funded multi- } \\
\text { sectoral nutritional } \\
\text { programme surveying all } \\
\text { three agro-ecological } \\
\text { zones of Nepal } \\
\text {-Diet diversity, maternal } \\
\text { and child anthropometrics } \\
\text { from 3,332 households } \\
\text { with children below age of } \\
5 \text { years and WEAI } \\
\text { administered to women in } \\
\text { Nepal (2012) } \\
\text {-Correlates } \\
\text { empowerment from WEAI } \\
\text { and production diversity } \\
\text { in agriculture } \\
\text {-OLS regression }\end{array}$ & $\begin{array}{l}\text { Production diversity, } \\
\text { women's group } \\
\text { membership, } \\
\text { reduced workload, } \\
\text { control over income } \\
\text { are associated with } \\
\text { improved nutritional } \\
\text { outcomes for women } \\
\text { and children }\end{array}$ \\
\hline & & $\begin{array}{l}\text { Sraboniet al., } \\
2014\end{array}$ & $\begin{array}{l}\text {-Nationally representative } \\
\text { Bangladesh Integrated } \\
\text { Household Survey (BIHS), } \\
\text { 2012, conducted by IFPRI. } \\
\text {-Household level per } \\
\text { capita calorie availability, } \\
\text { dietary diversity and adult } \\
\text { BMI from 3,273 household } \\
\text {-Correlates from WEAI } \\
\text {-OLS and 2SLS regression }\end{array}$ & $\begin{array}{lr}\text { Higher WEAI } & \text { scores } \\
\text { associated with } \\
\text { higher per adult } \\
\text { calorie availability } \\
\text { and dietary diversity } \\
\text { though } r \text { wealth, } \\
\text { education and } \\
\text { occupation } \\
\text { stronger } \\
\text { determinants }\end{array}$ \\
\hline 3 & Factor analysis & $\begin{array}{l}\text { Miedemaet al., } \\
(2018)\end{array}$ & 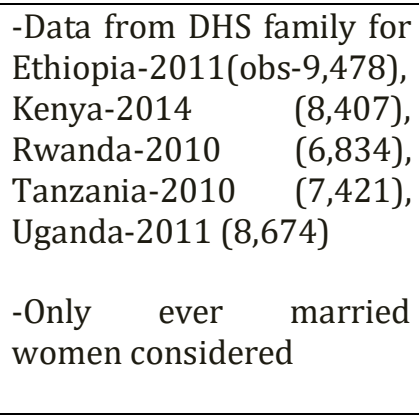 & $\begin{array}{l}\text {-The } 3 \text { domain multi- } \\
\text { dimensional model of } \\
\text { empowerment has } \\
\text { an invariant } \\
\text { structure for the East } \\
\text { African countries and } \\
\text { hence could be used } \\
\text { for a comparable and } \\
\text { standardized } \\
\text { measure of women's }\end{array}$ \\
\hline
\end{tabular}




\begin{tabular}{|c|c|c|c|c|}
\hline & Method & $\begin{array}{l}\text { Empirical } \\
\text { Studies }\end{array}$ & Study details & Findings \\
\hline & & & $\begin{array}{l}\text {-Identify } 3 \text { domains of } \\
\text { empowerment capturing } \\
\text { social assets, participation } \\
\text { in household decisions, } \\
\text { gender attitudes to wife } \\
\text { abuse } \\
\text {-Confirmatory factor } \\
\text { analysis }\end{array}$ & $\begin{array}{l}\text { empowerment in the } \\
\text { region }\end{array}$ \\
\hline & & $\begin{array}{l}\text { Sinharoy et al., } \\
(2018)\end{array}$ & $\begin{array}{l}\text {-Primary data collected } \\
\text { from Habiganj district of } \\
\text { Bangladesh in } 2015 \text { (obs- } \\
\text { 2,599) } \\
\text { - Only married women in } \\
\text { [15-40] age group } \\
\text { considered } \\
\text {-Exploratory and } \\
\text { confirmatory factor } \\
\text { analysis with structural } \\
\text { equation modeling to } \\
\text { study pathways between } \\
\text { empowerment (proxied by } \\
\text { highest level of education } \\
\text { and agency)and nutrition }\end{array}$ & $\begin{array}{l}\text {-3 latent domains of } \\
\text { women's agency } \\
\text { identified in social } \\
\text { solidarity, decision } \\
\text { making, voice with } \\
\text { husband. Higher } \\
\text { levels of education } \\
\text { positively associated } \\
\text { with increased diet } \\
\text { diversity both } \\
\text { directly and } \\
\text { indirectly via voice } \\
\text { with husband }\end{array}$ \\
\hline \multirow[t]{2}{*}{4} & \multirow[t]{2}{*}{$\begin{array}{l}\text { Regression } \\
\text { Decomposition }\end{array}$} & $\begin{array}{l}\text { Menonet al., } \\
(2018)\end{array}$ & $\begin{array}{l}\text {-NFHS-4 dataset for India } \\
\text { (2015) with 601,509 } \\
\text { household covered across } \\
\text { India covering } 640 \\
\text { districts in } 36 \text { states } \\
\text {-Underlying determinants } \\
\text { or covariates from UNICEF } \\
\text { (1990) and Lancet (2013) } \\
\text { framework } \\
\text {-HAZ scores for children } \\
\text { below the age of } 5 \text { years } \\
\text {-OLS regression }\end{array}$ & $\begin{array}{l}\text {-Women's BMI and } \\
\text { their education } \\
\text { appear to be the } \\
\text { strongest drivers of } \\
\text { malnutrition in } \\
\text { children }\end{array}$ \\
\hline & & $\begin{array}{l}\text { Headeyet al., } \\
\text { (2017) }\end{array}$ & $\begin{array}{l}\text {-Repeated cross sections } \\
\text { of DHS data for } \\
\text { Bangladesh (obs-28,043), } \\
\text { Nepal (10,608), Ethiopia } \\
(14,390) \text {, Odisha }(2,540) \\
\text { (India), Senegal }(7,727) \text {, } \\
\text { Zambia }(13,174) \\
\text {-HAZ scores for children } \\
\text { below age of } 5 \text { years } \\
\text {-Underlying determinants }\end{array}$ & $\begin{array}{l}\text { Improvements in } \\
\text { household assets, } \\
\text { mother's education } \\
\text { and access to } \\
\text { antenatal care are } \\
\text { strong } \\
\text { drivers of nutritional } \\
\text { improvement for } \\
\text { most countries }\end{array}$ \\
\hline
\end{tabular}




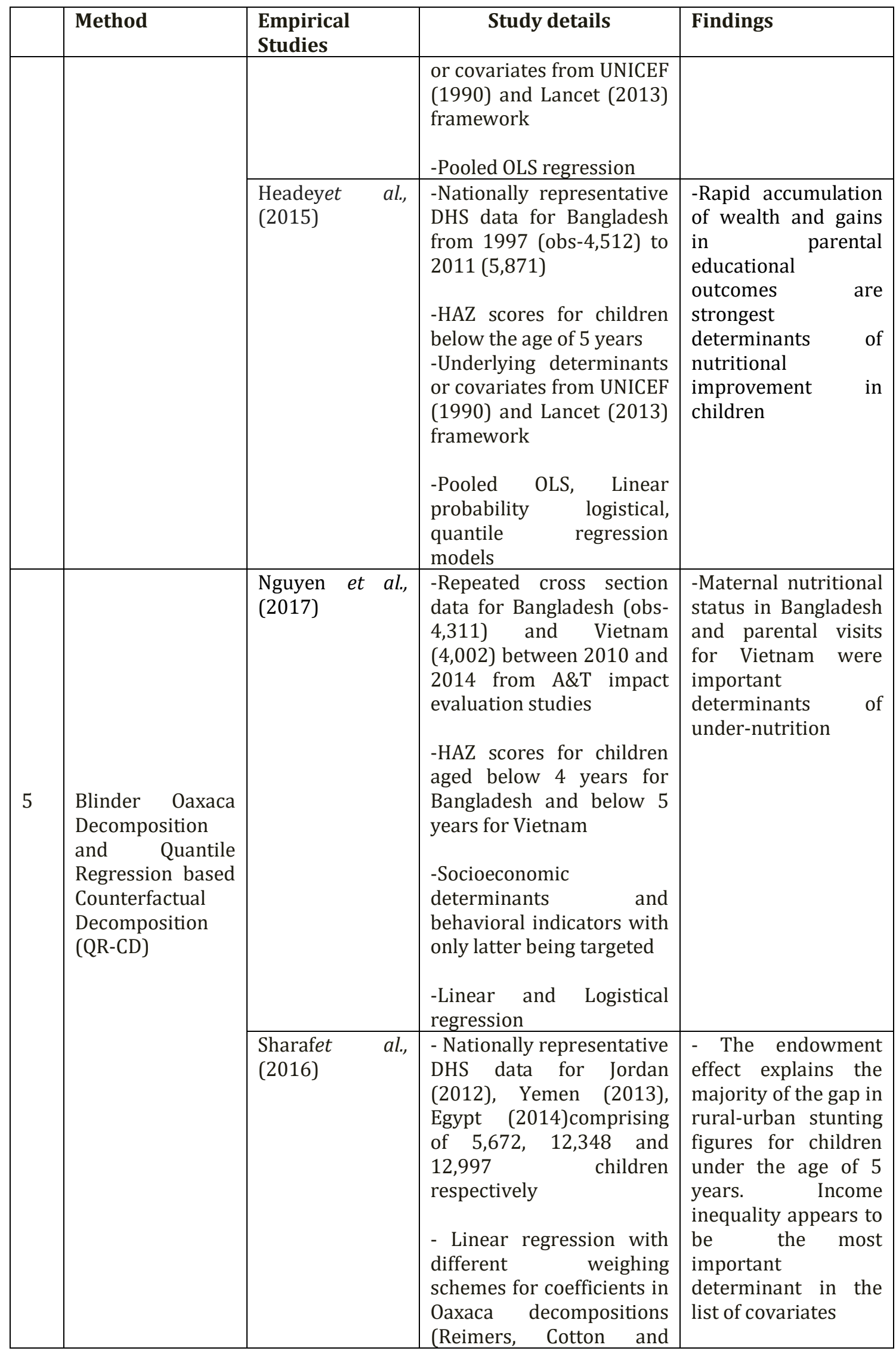




\begin{tabular}{|c|c|c|c|c|}
\hline & Method & $\begin{array}{l}\text { Empirical } \\
\text { Studies }\end{array}$ & Study details & Findings \\
\hline & & & Neumark) & \\
\hline & & $\begin{array}{l}\text { Cavatortaet al., } \\
(2015)\end{array}$ & $\begin{array}{l}\text {-Nationally representative } \\
\text { data for India (obs-8,997) } \\
\text { from NFHS-3, 2005 } \\
\text {-HAZ scores for children } \\
\text { under the age of } 5 \text { years } \\
\text {-Covariates include } \\
\text { underlying determinants } \\
\text { from the UNICEF and } \\
\text { Lancet framework } \\
\text { subsequently refined } \\
\text { based on model fit } \\
\text {-OLS Regression } \\
\text { - QR-CD method }\end{array}$ & $\begin{array}{l}\text {-Differences in child } \\
\text { stunting across } \\
\text { states is explained } \\
\text { less by endowment } \\
\text { effect and more by } \\
\text { coefficient effect }\end{array}$ \\
\hline & & $\begin{array}{ll}\text { Srinivasan, } & \text { et } \\
\text { al., } 2013\end{array}$ & $\begin{array}{l}\text {-Nationally representative, } \\
\text { DHS data for Nepal (2006) } \\
\text { and Bangladesh (2007) } \\
\text { with 5,219 and 5,267 } \\
\text { children below the age of } 5 \\
\text { years } \\
\text {-HAZ scores for rural and } \\
\text { urban groups of children } \\
\text { below the age of } 5 \text { years } \\
\text { across the two countries } \\
\text { - QR-CD method }\end{array}$ & $\begin{array}{l}\text { - Differences in socio- } \\
\text { economic } \\
\text { characteristics, } \\
\text { particularly maternal } \\
\text { and paternal } \\
\text { education, wealth } \\
\text { explain the wedge in } \\
\text { stunting for the } \\
\text { lowest quintile } \\
\text { across rural and } \\
\text { urban regions of the } \\
\text { two countries }\end{array}$ \\
\hline 6 & $\begin{array}{l}\text { Variance } \\
\text { decomposition }\end{array}$ & $\begin{array}{l}\text { Desai and } \\
\text { Thorat (2013) }\end{array}$ & $\begin{array}{l}\text {-Repeated cross section } \\
\text { for India from NFHS-1 } \\
(1992-93) \text { and NFHS-3 } \\
(2005-06)(\text { obs-8,997) }\end{array}$ & $\begin{array}{l}\text {-Declining role of } \\
\text { geography } \\
\text { stunting as variance } \\
\text { in HAZ declining } \\
\text { across village and } \\
\text { urban blocks }\end{array}$ \\
\hline
\end{tabular}


